\title{
MEKANISME SUKU BUNGA SBI SEBAGAI SASARAN OPERASIONAL KEBIJAKAN MONETER DAN VARIABEL MAKROEKONOMI INDONESIA: 1990.1 - 2007.4
}

\author{
Nova Riana Banjarnahor ${ }^{1}$
}

\begin{abstract}
Bank Indonesia has applied the Inflation Targeting Framework (ITF) to reach its single-final objective; stabilizing Rupiah reflected in the inflation and its exchange rate. The central bank of Indonesia uses the interest rate as his operational target to achieve the targeted inflation. Regardless of whether Bank Indonesia uses the Certificate of Bank Indonesia (SBI) or the money market rate (PUAB), on empirical ground the targeted inflation is hard to achieve.

This paper analyzes the monetary policy of Bank Indonesia and its impact on macroeconomic variables. The application of Differenced Vector Autoregressive (DVAR) method shows that the monetary policy has a direct impact on the time deposit rate and an indirect impact on the exchange rate, money supply, gross domestic product and on consumer's price index.
\end{abstract}

JEL Classification: C32, E52, E58

Keywords: SBI Interest Rate Mechanism, DVAR, IRF, FEVD

1 Alumni Fakultas Ekonomika dan Bisnis UGM. Penulis menyampaikan ucapan terimakasih kepada Prof. Dr. Insukindro M.A. atas segala bimbingan dan bantuan dalam penulisan artikel ini. 


\section{PENDAHULUAN}

\section{I.1. Latar Belakang}

Undang-undang No. 23 Tahun 1999 tentang Bank Indonesia (BI) sebagaimana telah diamandemen dengan Undang-undang No. 3 Tahun 2004 pada Pasal 7 menyatakan bahwa Indonesia telah menganut kebijakan moneter dengan tujuan tunggal yakni mencapai dan memelihara kestabilan nilai rupiah. Stabilitas nilai rupiah terhadap barang dan jasa dapat tercermin pada perkembangan laju inflasi dan stabilitas nilai rupiah terhadap mata uang negara lain tercermin pada perkembangan nilai tukar rupiah.

Kebijakan moneter dengan tujuan stabilisasi nilai rupiah mulai diterapkan sejak tahun 2000. Tujuan tunggal kebijakan moneter BI tersebut terangkum dalam kerangka strategis penargetan inflasi (inflation targeting). Penargetan inflasi adalah sebuah kerangka kerja untuk kebijakan moneter yang ditandai dengan pengumuman kepada masyarakat tentang angka target inflasi dalam satu periode tertentu (Warjiyo dkk, 2003: 113). Penargetan inflasi secara eksplisit menyatakan bahwa tujuan akhir kebijakan moneter adalah mencapai dan menjaga tingkat inflasi yang rendah dan stabil.

Berkaitan dengan tujuan penargetan inflasi, yaitu untuk mencapai laju inflasi yang rendah dan stabil dalam jangka panjang, maka pemerintah dan BI menetapkan bahwa sasaran inflasi jangka menengah dan panjang yang ingin dicapai adalah sebesar 3\%. Untuk mencapai keinginan tersebut, Pemerintah dan BI menetapkan sasaran inflasi jangka pendek yang harus dicapai setiap tahun. Sasaran inflasi yang pernah ditetapkan serta realisasinya setiap tahun dapat ditunjukkan pada tabel berikut.

\begin{tabular}{|c|c|c|c|}
\hline \multicolumn{4}{|c|}{$\begin{array}{c}\text { Tabel III.1 } \\
\text { Sasaran Inflasi dan Realisasinya }\end{array}$} \\
\hline Tahun & $\begin{array}{l}\text { Sasaran inflasi } \\
\text { yang diinginkan }\end{array}$ & $\begin{array}{c}\text { Tingkat Inflasi Akhir } \\
\text { Periode }\end{array}$ & $\begin{array}{c}\text { Pencapaian sasaran } \\
\text { inflasi }\end{array}$ \\
\hline 2000 & $3,0-5,0 \%$ & $9,4 \%$ & Tidak Tercapai \\
\hline 2001 & $4,0-6,0 \%$ & $12,5 \%$ & Tidak Tercapai \\
\hline 2002 & $9,0-10,0 \%$ & $10,0 \%$ & Tercapai \\
\hline 2003 & $8,0-10,0 \%$ & $5,2 \%$ & Tidak Tercapai \\
\hline 2004 & $6,0-8,0 \%$ & $6,4 \%$ & Tercapai \\
\hline 2005 & $5,0-7,0 \%$ & $17,1 \%$ & Tidak Tercapai \\
\hline 2006 & $4,5-6,5 \%$ & $6,6 \%$ & Tidak Tercapai \\
\hline 2007 & $4,0-6,0 \%$ & $6,6 \%$ & Tidak Tercapai \\
\hline 20061) & $7,0-9,0 \%$ & $6,6 \%$ & Tidak Tercapai \\
\hline 20071) & $5,0-7,0 \%$ & $6,6 \%$ & Tercapai \\
\hline
\end{tabular}


Pada tahun 2005 tingkat inflasi yang terjadi jauh berbeda dari perkiraan yang telah ditetapkan. Tingkat inflasi yang tinggi pada tahun 2005 tersebut terjadi sebagai akibat dari kenaikan harga minyak dunia. Harga minyak dunia yang mengalami kenaikan mengakibatkan inflasi naik secara tajam dan kenaikan tersebut tidak dapat diantisipasi oleh BI sebelumnya. Berkaitan dengan adanya peningkatan harga minyak dunia pada tahun 2005 tersebut, BI melakukan revisi sasaran inflasi tahun 2006 dan 2007.

Pada tahun 2003 dan 2006 setelah revisi tingkat inflasi yang terjadi lebih rendah dari sasaran inflasi yang telah ditetapkan sebelumnya. Sasaran inflasi pada kedua tahun tersebut tetap saja dapat dinyatakan tidak tercapai karena tingkat inflasi yang lebih rendah dari sasaran inflasi yang telah ditetapkan menunjukkan bahwa penghitungan sasaran inflasi yang telah ditetapkan tidak tepat. Dari Tabel III.1 tersebut dapat dinyatakan bahwa secara umum target inflasi setiap tahun yang telah ditetapkan oleh BI belum dapat tercapai sepenuhnya.

Sementara itu, sejak tanggal 14 Agustus 1997 pemerintah menetapkan sistem nilai tukar yang dianut adalah sistem nilai tukar mengambang bebas. Dalam sistem nilai tukar mengambang bebas, nilai tukar dibiarkan bergerak sesuai dengan kekuatan permintaan dan penawaran yang terjadi di pasar. Sistem nilai tukar mengambang bebas memungkinkan terjadinya nilai tukar yang sangat fluktuatif sehingga dapat menambah ketidakpastian bagi dunia usaha. Yang dapat dilakukan oleh BI adalah menjaga agar fluktuasinya tidak tinggi. Kenyataan ini menimbulkan pertanyaan sejauh mana tujuan BI seperti tertera pada Undang-undang tentang BI dapat dicapai.

Dalam penerapan penargetan inflasi, kerangka kebijakan moneter dijalankan dengan pendekatan berdasarkan harga besaran moneter. Kebijakan moneter dengan pendekatan harga menggunakan suku bunga sebagai sasaran operasionalnya. Sejalan dengan penerapan sistem nilai tukar mengambang bebas dan sesuai dengan amanat Undang-undang No. 23 Tahun 1999 maka BI mewacanakan penggunaan suku bunga Sertifikat Bank Indonesia (SBI) sebagai sasaran operasional kebijakan moneter (Kharie, 2006). Kebijakan tersebut memiliki tujuan untuk meningkatkan efektivitas kebijakan moneter yang berpendekatan harga di bawah sistem nilai tukar mengambang bebas. Sementara itu, Warjiyo dan Zulverdi (1998) menyatakan bahwa suku bunga yang cocok dijadikan sebagai sasaran operasional kebijakan moneter adalah suku bunga Pasar Uang Antar Bank (PUAB). Pemilihan suku bunga PUAB sebagai sasaran operasional karena pertimbangan bahwa suku bunga PUAB memiliki kaitan yang erat dengan suku bunga deposito, mencerminkan kondisi likuiditas di pasar uang, dan sekaligus dapat dipengaruhi oleh instrumen operasi pasar terbuka.

Mulai Juli 2005, suku bunga BI Rate dipergunakan sebagai sinyal respon kebijakan moneter dan sasaran operasional. BI Rate adalah suku bunga dengan tenor satu bulan yang diumumkan oleh BI secara periodik untuk jangka waktu tertentu yang berfungsi sebagai sinyal kebijakan 
moneter (www.bi.go.id). BI Rate diimplementasikan melalui operasi pasar terbuka untuk SBI satu bulan karena beberapa pertimbangan. Pertama, SBI satu bulan telah dipergunakan sebagai benchmark oleh perbankan dan pelaku pasar di Indonesia dalam berbagai aktivitasnya. Kedua, penggunaan SBI satu bulan sebagai sasaran operasional akan memperkuat sinyal respon kebijakan moneter yang ditempuh BI. Ketiga, dengan perbaikan kondisi perbankan dan sektor keuangan, SBI satu bulan terbukti mampu mentransmisikan kebijakan moneter ke sektor keuangan dan ekonomi.

Terdapat beberapa penelitian yang relevan mengenai pengaruh kebijakan moneter melalui suku bunga terhadap beberapa variabel makroekonomi pada satu atau beberapa negara. Cheng (2006) menganalisis dampak kejutan kebijakan moneter di negara Kenya. Cheng (2006) menyatakan bahwa peningkatan suku bunga jangka pendek cenderung diikuti oleh penurunan tingkat harga dan apresiasi nilai tukar nominal, namun tidak memiliki dampak yang signifikan terhadap output. Dabla-Norris dan Floerkemeier (2006) menganalisis dampak kebijakan moneter di negara Armenia. Dabla-Norris dan Floerkemeier (2006) menunjukkan bahwa kemampuan kebijakan moneter dalam mempengaruhi aktivitas ekonomi dan inflasi masih terbatas. Jalur suku bunga tetap lemah dalam mempengaruhi output, namun terdapat pengaruh yang kecil dari kejutan suku bunga terhadap harga.

Penelitian mengenai topik yang relevan di Indonesia sendiri telah banyak dilakukan. Julaihah dan Insukindro (2004) menyatakan bahwa suku bunga SBI mampu mempengaruhi pergerakan suku bunga deposito satu bulan, IHK, tingkat output, dan nilai tukar. Bahkan, kejutan suku bunga SBI mampu memberi kontribusi dalam menjelaskan variabilitas pertumbuhan ekonomi meskipun dalam jangka panjang. Selanjutnya, Solikin (2005) menyatakan bahwa suku bunga SBI berpengaruh secara signifikan dan persisten hanya pada inflasi. Namun, pengaruhnya terhadap pertumbuhan output dan kesempatan kerja relatif kecil. Selain itu, Nuryati, Siregar dan Ratnawati (2006) menyatakan bahwa suku bunga SBI hanya berpengaruh sangat kecil terhadap tingkat harga dan nilai tukar.

Walaupun terdapat beberapa penelitian terdahulu mengenai dampak kebijakan moneter terhadap variabel ekonomi, penelitian ini tetap penting untuk dilakukan. Pengukuran yang tepat mengenai dampak perubahan kebijakan moneter terhadap ekonomi sangatlah penting, baik untuk membuat kebijakan yang tepat maupun untuk memilih diantara alternatif teori makroekonomi (Bernanke dan Mihov, 1998). Sementara itu, masih terdapat ketidakpastian yang besar mengenai dampak kebijakan moneter pada aktivitas ekonomi dan harga (Fung, 2002). 


\section{I.2. Perumusan Masalah}

Tugas pokok BI saat ini menjadi lebih fokus karena memiliki sasaran tunggal. Namun, dalam pelaksanaannya tugas tersebut cukup berat mengingat kestabilan nilai rupiah tidak sepenuhnya dapat dikendalikan oleh BI. BI hanya memiliki kemampuan untuk mempengaruhi tekanan inflasi dari sisi permintaan, sedang tekanan inflasi yang berasal dari sisi penawaran sepenuhnya berada diluar pengendalian BI. Demikian pula, dengan ditetapkannya sistem nilai tukar mengambang bebas maka nilai tukar rupiah akan sepenuhnya ditetapkan oleh kekuatan pasar.

Tujuan tunggal kebijakan moneter BI untuk menjaga stabilitas nilai rupiah terangkum dalam kerangka kerja penargetan inflasi. Dalam penerapan penargetan inflasi, kebijakan moneter dijalankan dengan menggunakan suku bunga sebagai sasaran operasionalnya. Sementara itu, pemilihan suku bunga yang dijadikan sebagai sasaran operasional kebijakan moneter masih meninggalkan perdebatan. Perdebatan tersebut berkisar pada apakah suku bunga SBI atau suku bunga PUAB yang tepat dijadikan sebagai sasaran operasional kebijakan moneter. Penelitian ini menggunakan suku bunga SBI sebagai sasaran operasional untuk mengetahui kemampuan suku bunga SBI sebagai sasaran operasional dalam mentransmisikan kebijakan moneter pada beberapa variabel makroekonomi Indonesia.

Pada penelitian ini, analisis mengenai peranan suku bunga SBI dalam mentransmisikan kebijakan moneter tersebut diperoleh dengan melakukan analisis mengenai respon inflasi, nilai tukar dan beberapa variabel makroekonomi lainnya terhadap kejutan suku bunga SBI. Atau, analisis mengenai respon perubahan inflasi, nilai tukar dan beberapa variabel makroekonomi lainnya terhadap kejutan perubahan suku bunga SBI. Selain itu, analisis lain yang dapat dilakukan adalah analisis mengenai kemampuan kejutan suku bunga SBI atau kejutan perubahannya dalam menjelaskan variasi beberapa variabel makroekonomi Indonesia atau variasi perubahannya. Hal-hal tersebutlah yang menjadi masalah yang akan dianalisis dalam penelitian ini. Permasalahan tersebut akan dikaji dengan menggunakan analisis model Vector Autoregression (VAR) atau model differensi pertama VAR (DVAR).

\section{TEORI}

Mekanisme transmisi kebijakan moneter merupakan proses pengaruh kebijakan moneter terhadap sektor keuangan dan sektor riil (Warjiyo, 2004). Secara umum, terdapat enam jenis saluran tranmisi kebijakan moneter yang sering dikemukakan dalam teori ekonomi moneter. Saluran transmisi tersebut antara lain saluran uang, saluran suku bunga, saluran nilai tukar, saluran harga aset, saluran kredit, dan saluran ekspektasi. Masing-masing saluran transmisi tersebut menjelaskan mengenai alur pengaruh kebijakan moneter terhadap sektor keuangan dan aktivitas ekonomi. 
Dalam penerapan penargetan inflasi, kerangka kebijakan moneter dijalankan dengan pendekatan berdasarkan harga besaran moneter. Kebijakan moneter dengan pendekatan harga besaran moneter dapat berpengaruh efektif terhadap pengendalian tingkat inflasi melalui saluran suku bunga dan nilai tukar (Kharie, 2006). Pada penelitian ini sasaran operasional yang digunakan adalah suku bunga SBI satu bulan. Sementara itu, variabel-variabel informasi yang digunakan, antara lain suku bunga deposito satu bulan, jumlah uang beredar dalam arti sempit (M1), PDB, dan nilai tukar yang juga mencerminkan stabilitas nilai rupiah terhadap mata uang negara lain. Mekanisme transmisi yang digunakan untuk menjelaskan pengaruh suku bunga SBI terhadap variabel analisis lainnya dapat ditunjukkan dengan gambar berikut.

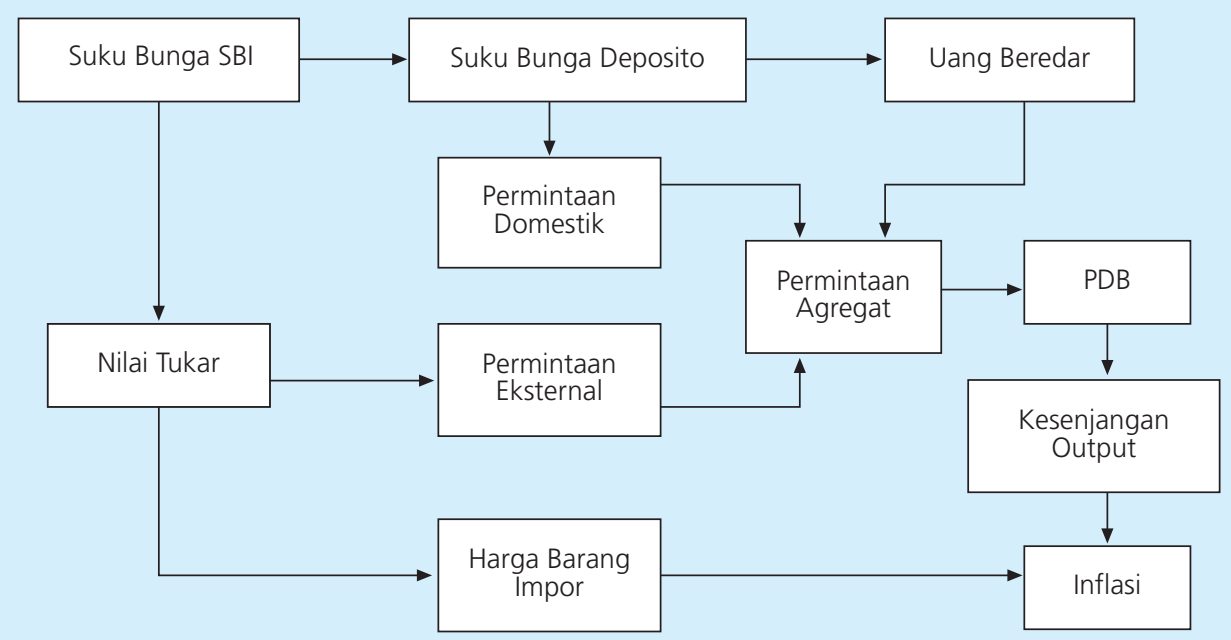

Sumber: Warjiyo, 2004: 29 (dimodifikasi)

Gambar III.1

Skema Mekanisme Transmisi Jalur Suku Bunga SBI

Dari skema di atas terlihat bahwa kebijakan moneter yang ditempuh BI dengan menjalankan instrumen kebijakannya akan berpengaruh terhadap perkembangan suku bunga SBI sebagai sasaran operasional kebijakan moneter. Ketika suku bunga SBI dinaikkan maka suku bunga deposito akan meningkat juga, jumlah uang beredar akan menurun, dan nilai tukar akan mengalami apresiasi. Mata uang domestik mengalami apresiasi melalui peningkatan arus modal masuk atau peningkatan penawaran mata uang asing dalam pasar valuta asing. 
Berbagai perkembangan variabel ekonomi tersebut menyebabkan penurunan jumlah konsumsi dan investasi (sebagai komponen permintaan domestik) serta peningkatan jumlah ekspor dan impor (sebagai komponen permintaan eksternal) (Warjiyo, 2004). Dengan asumsi bahwa permintaan domestik lebih besar dibandingkan dengan permintaan eksternal maka perkembangan permintaan domestik dan eksternal ini menghasilkan penurunan nilai permintaan agregat. Penurunan permintaan agregat tersebut berarti bahwa nilai Produk Domestik Bruto (PDB) menurun. Besarnya permintaan agregat tersebut tidak selamanya seimbang dengan besarnya penawaran agregat yang ditentukan oleh volume produksi barang dan jasa secara nasional.

Dengan asumsi bahwa penawaran agregat tidak mengalami perubahan, maka penurunan permintaan agregat akan mengakibatkan kesenjangan output semakin kecil. Kesenjangan output yang terjadi dalam ekonomi tersebut akan menimbulkan tekanan inflasi yang semakin kecil dari sisi domestik. Selain itu, apresiasi nilai tukar memiliki pengaruh langsung terhadap perkembangan harga barang-barang yang diimpor dari luar negeri. Apresiasi nilai tukar menyebabkan harga barang impor semakin murah sehingga menimbulkan tekanan inflasi yang lebih kecil dari sisi eksternal. Tekanan inflasi dari sisi domestik dan eksternal yang semakin kecil ini mengakibatkan turunnya tingkat inflasi.

\section{METODOLOGI}

\section{III.1. Data}

Dalam penelitian ini, data yang digunakan adalah data sekunder dari publikasi BI dan International Financial Statistics(IFS). Data yang digunakan adalah data triwulanan periode 1990.1 - 2007.4. Penelitian ini memilih periode tersebut karena periode 1990.1 - 2000.1 merupakan periode transisi menuju penerapan penargetan inflasi pascaliberalisasi keuangan akhir dekade 80-an dan periode setelah 2000.1 merupakan periode penerapan penargetan inflasi.

Data yang digunakan dalam penelitian ini adalah sebagai berikut.

1. Suku bunga Sertifikat Bank Indonesia (SBI) adalah suku bunga SBI dengan tenor satu bulan.

2. Suku bunga Deposito (DEP) adalah suku bunga simpanan berjangka rupiah menurut kelompok bank umum dengan tenor satu bulan.

3. Nilai tukar (KURS) adalah nilai tukar rupiah terhadap dolar Amerika

4. Uang beredar dalam arti sempit (M1) adalah uang kartal dan uang giral.

5. Produk Domestik Bruto (PDB) adalah PDB menurut lapangan usaha atas dasar harga konstan tahun 2000.

6. Indeks Harga Konsumen (IHK) adalah indeks harga umum berdasarkan harga konstan dengan tahun dasar 2000. 


\section{III.2. Alat Analisis}

Penelitian ini akan menggunakan Vector Autoregression (VAR) sebagai alat analisis. Secara umum, VAR digunakan untuk menganalisis sistem variabel-variabel runtun waktu dan untuk menganalisis dampak dinamis dari faktor kejutan yang terdapat dalam sistem variabel tersebut. Analisis VAR dilakukan dengan mempertimbangkan beberapa variabel endogen secara bersamasama dalam satu model. Masing-masing variabel endogen tersebut dijelaskan oleh nilainya di masa lampau (tenggat) dan nilai masa lalu dari semua variabel endogen lainnya dalam model yang dianalisis.

Penelitian akan memilih model yang digunakan berdasarkan hasil pengujian stasioneritas data. Apabila semua data stasioner pada tingkat aras maka model yang dipilih adalah VAR pada tingkat aras. Namun, apabila data stasioner pada differensi pertama maka model yang dipilih adalah VAR pada differensi pertama. VAR pada differensi pertama ini sering disebut sebagai Difference of VAR (DVAR).

Analisis VAR atau DVAR ini akan memuat analisis Impulse Response Function (IRF) dan Forecast Error Variance Decomposition (FEVD). Estimasi terhadap IRF dilakukan untuk menganalisis respon beberapa variabel makroekonomi atau respon perubahan variabel makroekonomi terhadap kejutan suku bunga SBI atau kejutan perubahan suku bunga SBI. Estimasi terhadap FEVD bertujuan untuk menganalisis dampak kejutan suku bunga SBI atau kejutan perubahan suku bunga SBI dalam menjelaskan variasi variabel makroekonomi atau variasi perubahan variabel makroekonomi.

\section{III.3. Model Analisis}

Apabila data yang dianalisis merupakan data yang stasioner pada tingkat aras maka sistem persamaan VAR dalam penelitian ini dapat disusun sebagai berikut.

$$
\begin{aligned}
& \operatorname{SBI}_{\mathrm{t}}=\sum_{\mathrm{j}=1}^{\mathrm{n}} \operatorname{SBI}_{\mathrm{t}-\mathrm{j}}+\sum_{\mathrm{j}=1}^{\mathrm{n}} \operatorname{DEP}_{\mathrm{t}-\mathrm{j}}+\sum_{\mathrm{j}=1}^{\mathrm{n}} \mathrm{LNM1}_{\mathrm{t}-\mathrm{j}}+\sum_{\mathrm{j}=1}^{\mathrm{n}} \operatorname{LNKURS}_{\mathrm{t}-\mathrm{j}}+\sum_{\mathrm{j}=1}^{\mathrm{n}} \operatorname{LNPDB}_{\mathrm{t}-\mathrm{j}}+\sum_{\mathrm{j}=1}^{\mathrm{n}} \operatorname{LNIHK}_{\mathrm{t}-\mathrm{j}}+\varepsilon_{1 \mathrm{t}} \\
& \operatorname{DEP}_{t}=\sum_{j=1}^{n} \operatorname{DEP}_{t-j}+\sum_{j=1}^{n} \operatorname{SBI}_{t-j}+\sum_{j=1}^{n} \operatorname{LNM1}_{t-j}+\sum_{j=1}^{n} \operatorname{LNKURS}_{t-j}+\sum_{j=1}^{n} \operatorname{LNPDB}_{t-j}+\sum_{j=1}^{n} \text { LNIHK }_{t-j}+\varepsilon_{2 t} \\
& \mathrm{LNM1}_{\mathrm{t}}=\sum_{\mathrm{j}=1}^{\mathrm{n}} \mathrm{LNM1}_{\mathrm{t}-\mathrm{j}}+\sum_{\mathrm{j}=1}^{\mathrm{n}} \mathrm{SBI}_{\mathrm{t}-\mathrm{j}}+\sum_{\mathrm{j}=1}^{\mathrm{n}} \mathrm{DEP}_{\mathrm{t}-\mathrm{j}}+\sum_{\mathrm{j}=1}^{\mathrm{n}} \mathrm{LNKURS}_{\mathrm{t}-\mathrm{j}}+\sum_{\mathrm{j}=1}^{\mathrm{n}} \mathrm{LNPDB}_{\mathrm{t}-\mathrm{j}}+\sum_{\mathrm{j}=1}^{\mathrm{n}} \mathrm{LNIHK}_{\mathrm{t}-\mathrm{j}}+\varepsilon_{3 \mathrm{t}} \\
& \text { LNKURS }=\sum_{j=1}^{n} \operatorname{LNKURS}_{-j}+\sum_{j=1}^{n} \operatorname{SBI}_{t-j}+\sum_{j=1}^{n} \operatorname{DEP}_{t-j}+\sum_{j=1}^{n} \operatorname{LNM}_{t-j}+\sum_{j=1}^{n} \operatorname{LNPDB}_{t-j}+\sum_{j=1}^{n} \operatorname{LNIHK}_{t-j}+\varepsilon_{4 t}
\end{aligned}
$$


$\mathrm{LNPDB}_{\mathrm{t}}=\sum_{\mathrm{j}=1}^{\mathrm{n}} \mathrm{LNPDB}_{\mathrm{t}-\mathrm{j}}+\sum_{\mathrm{j}=1}^{\mathrm{n}} \mathrm{SBI}_{\mathrm{t}-\mathrm{j}}+\sum_{\mathrm{j}=1}^{\mathrm{n}} \mathrm{DEP}_{\mathrm{t}-\mathrm{j}}+\sum_{\mathrm{j}=1}^{\mathrm{n}} \mathrm{LNM}_{\mathrm{t}-\mathrm{j}}+\sum_{\mathrm{j}=1}^{\mathrm{n}} \mathrm{LNKURS}_{\mathrm{t}-\mathrm{j}}+\sum_{\mathrm{j}=1}^{\mathrm{n}} \mathrm{LNIHK}_{\mathrm{t}-\mathrm{j}}+\varepsilon_{5 \mathrm{t}}$ LNIHK $_{t}=\sum_{j=1}^{n}$ LNIHK $_{t-j}+\sum_{j=1}^{n}$ SBI $_{t-j}+\sum_{j=1}^{n} \operatorname{DEP}_{t-j}+\sum_{j=1}^{n}$ LNM $_{t-j}+\sum_{j=1}^{n}$ LNKURS $_{t-j}+\sum_{j=1}^{n}$ LNPDB $_{t-j}+\varepsilon_{6 t}$

Dengan demikian, jika data yang digunakan merupakan data yang stasioner pada differensi pertama maka sistem persamaan DVAR dapat disusun dengan terlebih dahulu mendifferensikan setiap variabel analisis.

\section{HASIL ANALISIS}

\section{IV.1. Deskripsi Hubungan Suku Bunga SBI dan Variabel Makroekonomi}

Pola hubungan suku bunga SBI dan beberapa variabel makroekonomi yang dianalisis dalam penelitian ini dapat ditunjukkan pada beberapa grafik berikut.

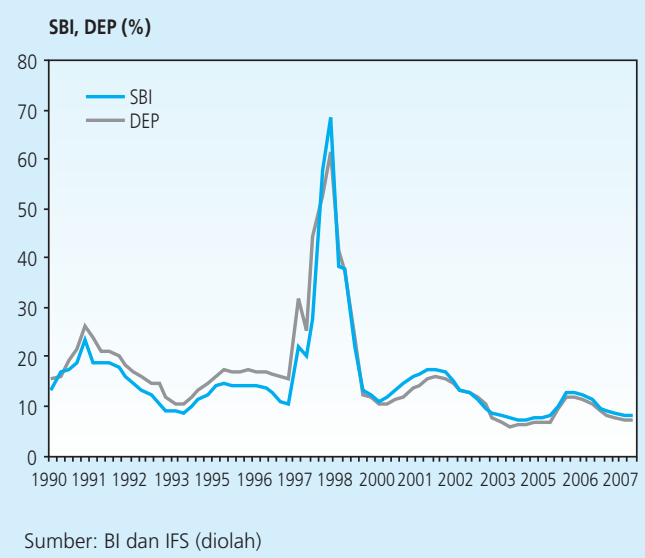

Grafik III.1 Hubungan Suku Bunga SBI dan Suku Bunga Deposito

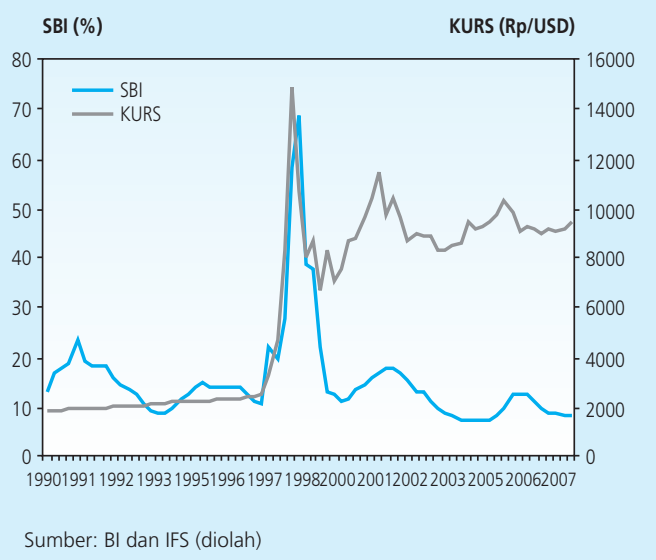

Grafik III.2

Hubungan Suku Bunga SBI dan Nilai Tukar 


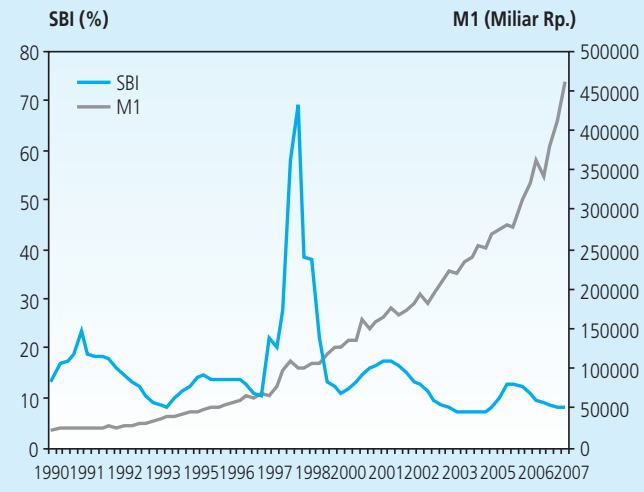

Sumber: BI dan IFS (diolah)

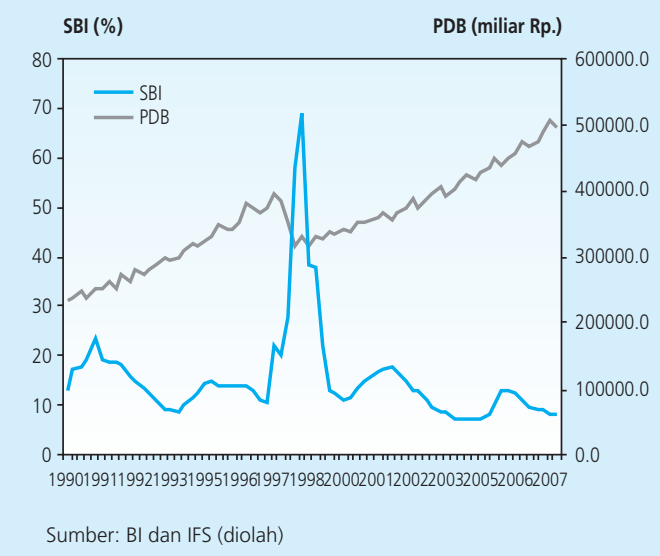

Grafik III.4

Hubungan suku bunga SBI dan PDB
Grafik III.3

Hubungan Suku Bunga SBI dan M1

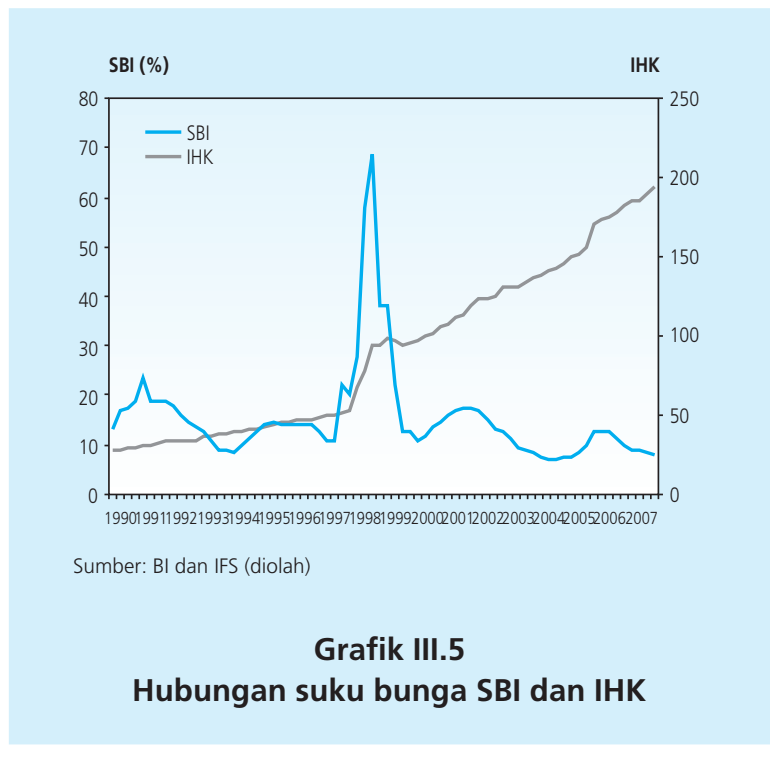

Secara umum, grafik pola hubungan suku bunga SBI dengan beberapa variabel makroekonomi yang dianalisis menunjukkan bahwa pergerakan suku bunga SBI hanya diikuti oleh suku bunga deposito selama periode 1990 - 2007. Sementara itu, pergerakan variabel KURS, M1, PDB, dan IHK tidak menyesuaikan dengan pergerakan suku bunga SBI selama periode 1990 - 2007. Dari gambaran ini dapat diduga bahwa kejutan suku bunga SBI hanya direspon 
dengan baik oleh variasi suku bunga deposito. Sementara, variasi variabel makroekonomi lainnya dalam analisis ini memberikan respon yang relatif kecil terhadap kejutan suku bunga SBI. Atau dengan kata lain dapat dinyatakan bahwa kejutan suku bunga SBI bukan merupakan variabel yang penting dan berpengaruh pada pergerakan variabel makroekonomi lainnya.

\section{IV.2. Hasil Estimasi Model VAR}

\section{IV.2.1. Uji Stasioneritas Data}

Uji stasioneritas data dilakukan pada setiap variabel analisis dengan menggunakan dua alat analisis uji akar-akar unit, yaitu Augmented Dickey Fuller (ADF) dan Phillips Perron (PP). Tujuan penggunaan dua metode uji stasioneritas data ini adalah untuk mendapatkan hasil stasioneritas data yang dapat dipercaya. Pengujian pada masing-masing variabel dimulai dengan pengujian stasioneritas pada tingkat aras dengan menggunakan kedua alat tersebut. Apabila variabel tidak stasioner pada tingkat aras maka pengujian dilanjutkan pada tingkat integrasi (differensi pertama) untuk mendapatkan data yang stasioner. Hasil uji stasioneritas data pada tingkat aras dirangkum pada Tabel III.2 di bawah ini.

\begin{tabular}{|c|c|c|c|c|c|c|c|}
\hline \multirow{3}{*}{ Variabel } & \multicolumn{6}{|c|}{$\begin{array}{c}\text { Tabel III.2 } \\
\text { Hasil Uji Stasioneritas Pada Tingkat Aras }\end{array}$} & \multirow{3}{*}{ Keterangan } \\
\hline & \multicolumn{3}{|c|}{ Uji ADF } & \multicolumn{3}{|c|}{ Uji PP } & \\
\hline & i & $i, t$ & $\mathbf{N}$ & I & $i, t$ & n & \\
\hline SBI & $-3.5795^{\star}$ & -3.6934 & -1.7496 & $-2.9299 *$ & -3.0464 & -1.5562 & Stasioner \\
\hline DEP & -3.4624 & $-3.7943^{*}$ & -1.8492 & $-2.4075^{\star}$ & -2.6909 & -1.3789 & Stasioner \\
\hline LNKURS & -1.3032 & $-2.1165^{*}$ & 0.9279 & -1.2069 & -1.9047 & $1.0816 *$ & $\begin{array}{l}\text { Tidak } \\
\text { Stasioner }\end{array}$ \\
\hline LNM1 & -0.0638 & $-1.9549 *$ & 3.9827 & 1.626871 & $-2.9371 *$ & 20.2518 & $\begin{array}{l}\text { Tidak } \\
\text { Stasioner }\end{array}$ \\
\hline LNPDB & -0.8399 & $-2.6347^{*}$ & 1.5788 & -0.9814 & $-2.4162^{*}$ & 4.2608 & $\begin{array}{l}\text { Tidak } \\
\text { Stasioner }\end{array}$ \\
\hline LNIHK & -0.5341 & $-2.0708^{*}$ & 2.9459 & -0.5237 & -1.9919 & $4.0250 *$ & $\begin{array}{l}\text { Tidak } \\
\text { Stasioner }\end{array}$ \\
\hline
\end{tabular}

Berdasarkan tabel hasil uji stasioneritas data pada tingkat aras tersebut maka dapat disimpulkan bahwa hanya variabel SBI dan DEP yang stasioner pada tingkat aras. Sementara, empat variabel analisis lainnya tidak stasioner pada tingkat aras. Oleh karena itu, pengujian stasioneritas data dilanjutkan pada tingkat differensi pertama. Hasil uji stasioneritas data pada tingkat differensi pertama dirangkum pada Tabel III.3. 


\begin{tabular}{|c|c|c|c|c|c|c|c|}
\hline \multirow{3}{*}{ Variabel } & \multicolumn{6}{|c|}{$\begin{array}{l}\text { Tabel III.3 } \\
\text { as Pada Tingkat Differensi Pertama }\end{array}$} & \multirow{3}{*}{ Keterangan } \\
\hline & \multicolumn{3}{|c|}{ Uji ADF } & \multicolumn{3}{|c|}{ Uji PP } & \\
\hline & $\mathbf{i}$ & $\mathrm{i}, \mathrm{t}$ & $\mathbf{N}$ & I & $\mathrm{i}, \mathrm{t}$ & n & \\
\hline $\mathrm{SBI}$ & -5.0354 & -5.0002 & $-5.0703 *$ & -7.1015 & -7.0516 & $-7.1503 *$ & Stasioner \\
\hline DEP & -5.1436 & -5.1045 & $-5.1671 *$ & -7.4256 & -7.3866 & $-7.4767 *$ & Stasioner \\
\hline LNKURS & -6.2148 & -5.0726 & $-6.1225^{*}$ & -6.2147 & -6.1874 & $-6.1331 *$ & Stasioner \\
\hline LNM1 & $-4.3433^{*}$ & -4.3098 & -1.4045 & $-10.5018^{*}$ & -10.2639 & -6.4477 & Stasioner \\
\hline LNPDB & $-3.0998 *$ & -3.0725 & -2.2214 & $-10.407^{*}$ & -10.3881 & -9.4896 & Stasioner \\
\hline LNIHK & $-4.5997 *$ & -4.5689 & -3.1687 & $-5.2543^{*}$ & -5.2211 & -3.7687 & Stasioner \\
\hline
\end{tabular}

Berdasarkan tabel tersebut, uji stasioneritas data pada differensi pertama memberikan hasil bahwa semua variabel stasioner pada differensi pertama.

\section{IV.2.2. Pemilihan Model VAR}

Berdasarkan uji stasioneritas yang telah dilakukan, model yang dipilih untuk dianalisis selanjutnya adalah model differensi VAR (DVAR). Pemilihan ini dilakukan karena hanya terdapat dua variabel yang stasioner pada tingkat aras, yaitu SBI dan DEP. Sementara itu, semua variabel adalah stasioner pada tingkat differensi pertama. Oleh karena itu, tahapan analisis selanjutnya akan menggunakan model DVAR.

\section{IV.2.3. Penentuan Tenggat Optimal}

Penentuan tenggat optimal dilakukan pada model DVAR. Untuk memperoleh panjang tenggat yang tepat akan dilakukan dua tahap pengujian. Pada tahap pertama, pengujian akan melihat panjang tenggat maksimum sistem DVAR yang stabil. Stabilitas sistem DVAR dilihat dari nilai inverse roots karakteristik AR polinominalnya. Pengujian stabilitas sistem DVAR akan dimulai dengan tenggat empat. Apabila DVAR dengan tenggat empat tidak stabil maka harus diuji lagi dengan tenggat lainnya.

Suatu sistem VAR dikatakan stabil (stasioner) jika seluruh akar-akar unit memiliki modulus lebih kecil dari satu dan semuanya terletak di dalam unit circle (Eviews 4 User's Guide, 2002: 522). Jika sistem VAR tidak stabil maka beberapa hasil (seperti standard error pada Impulse Response) akan tidak valid. Pada suatu sistem VAR akan terdapat kp akar-akar unit, dimana k merupakan jumlah variabel endogen yang dianalisis dan p merupakan tenggat maksimum yang digunakan. 
Hasil uji stabilitas sistem DVAR dengan tabel nilai modulus seluruh akar-akar unit ditunjukkan sebagai berikut.

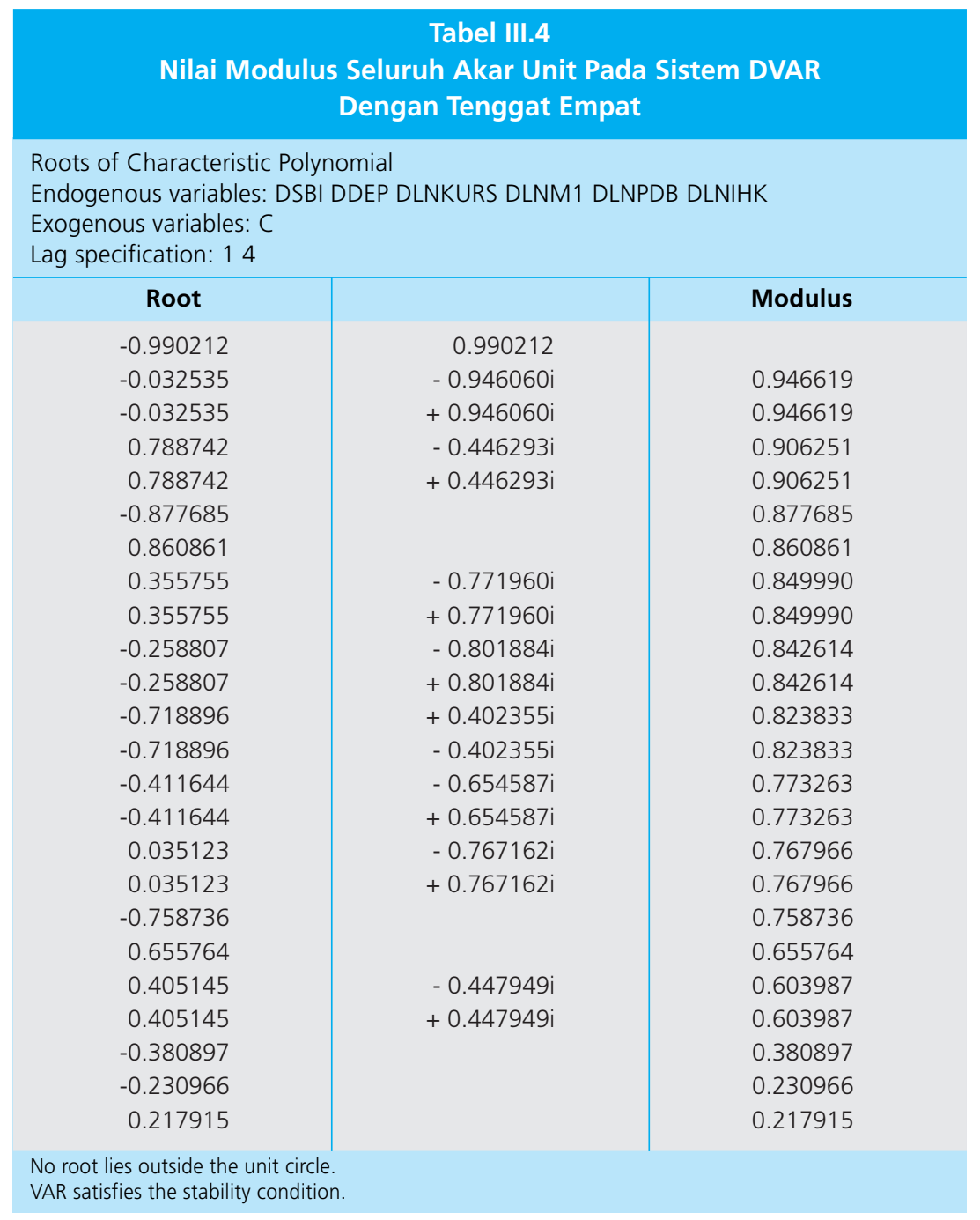

Hasil pengujian stabilitas sistem DVAR dengan tenggat empat menunjukkan bahwa seluruh akar-akar unitnya memiliki modulus lebih kecil dari satu. Oleh karena itu, sistem DVAR dengan tenggat empat merupakan sistem VAR yang memenuhi kondisi stabilitas.

Selain itu, hasil uji stabilitas sistem DVAR tersebut dapat juga ditunjukkan pada gambar sebagai berikut. 


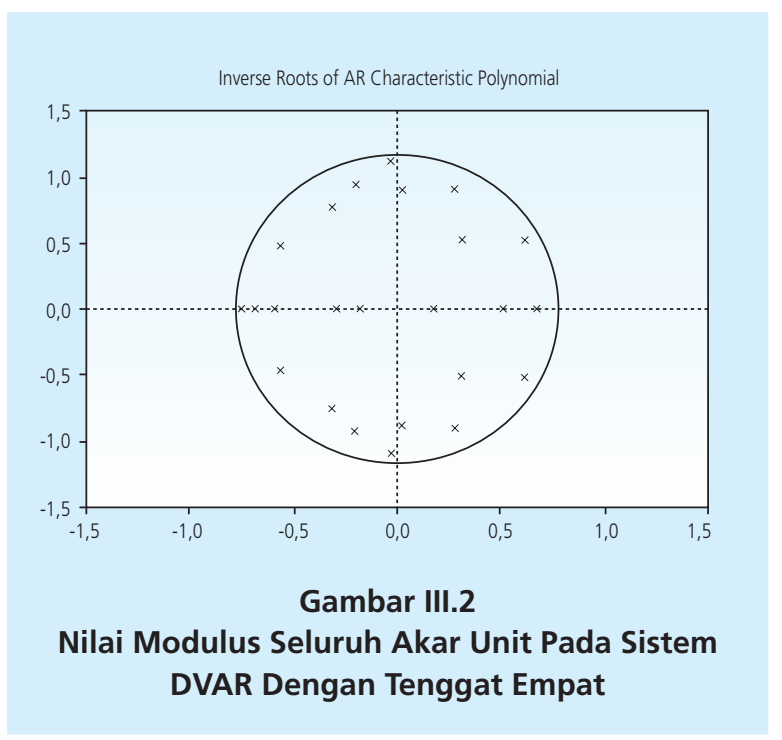

Dari gambar III.2 tersebut dapat dinyatakan bahwa seluruh akar unit terletak di dalam unit circle. Keadaan ini menunjukkan bahwa sistem DVAR yang terbentuk merupakan sistem yang stabil dan layak untuk diestimasi.

Pada tahap kedua penentuan tenggat optimal, panjang tenggat optimal akan dicari dengan menggunakan kriteria informasi yang tersedia. Kandidat tenggat yang terpilih adalah panjang tenggat menurut kriteria Likelihood Ratio (LR), Final Prediction Error (FPE), Akaike Information Criterion(AIC), Schwarz Information Criterion (SIC) dan Hannan-Quin Criterion (HQ). Penelitian ini akan memilih panjang tenggat optimal yang memberikan nilai AIC minimum (Gujarati, 2003: 849).

Hasil pemilihan tenggat optimal tersebut ditunjukkan pada tabel berikut.

\begin{tabular}{|c|c|c|c|c|c|c|c|}
\hline \multirow{3}{*}{ Variabel } & \multicolumn{6}{|c|}{$\begin{array}{c}\text { Tabel III.5 } \\
\text { ggat Optima }\end{array}$} & \\
\hline & \multicolumn{3}{|c|}{ Uji ADF } & \multicolumn{3}{|c|}{ Uji PP } & \\
\hline & i & $\mathrm{i}, \mathrm{t}$ & $\mathbf{N}$ & I & $\mathrm{i}, \mathrm{t}$ & $\mathbf{n}$ & \\
\hline SBI & -5.0354 & -5.0002 & $-5.0703^{*}$ & -7.1015 & -7.0516 & $-7.1503^{*}$ & Stasioner \\
\hline DEP & -5.1436 & -5.1045 & -5.1671 * & -7.4256 & -7.3866 & $-7.4767^{\star}$ & Stasioner \\
\hline LNKURS & -6.2148 & -5.0726 & $-6.1225^{*}$ & -6.2147 & -6.1874 & $-6.1331 *$ & Stasioner \\
\hline LNM1 & $-4.3433^{*}$ & -4.3098 & -1.4045 & $-10.5018^{*}$ & -10.2639 & -6.4477 & Stasioner \\
\hline LNPDB & $-3.0998 *$ & -3.0725 & -2.2214 & $-10.407^{\star}$ & -10.3881 & -9.4896 & Stasioner \\
\hline LNIHK & $-4.5997 *$ & -4.5689 & -3.1687 & $-5.2543^{\star}$ & -5.2211 & -3.7687 & Stasioner \\
\hline
\end{tabular}


Tabel hasil pemilihan tenggat optimal tersebut menunjukkan bahwa dari kelima kriteria yang digunakan, terdapat empat kriteria yang memilih tenggat empat sebagai tenggat optimal. Nilai AIC terkecil juga dihasilkan oleh tenggat empat. Oleh karena itu, penelitian ini menggunakan tenggat empat sebagai tenggat optimal.

\section{IV.2.4. Impulse Response Function (IRF)}

Analisis IRF yang dilakukan menggunakan 20 periode pengamatan dan metode Cholesky Decomposition. Penggunaan 20 periode pengamatan ini diasumsikan sudah cukup mewakili pengamatan analisis jangka pendek dan jangka panjang. Penggunaan metode Cholesky dimaksudkan agar urutan dalam IRF dapat disesuaikan dengan mekanisme transmisi kebijakan moneter yang dijelaskan pada bab sebelumnya. Hasil IRF yang diperoleh dari variabel analisis ditampilkan dalam bentuk grafik keseluruhan IRF (Grafik III.6). Grafik III.6 menunjukkan seluruh IRF variabel analisis. Namun, IRF yang akan dibahas adalah IRF yang berkaitan dengan tujuan penelitian ini. Penelitian ini hanya akan menganalisis dampak kejutan perubahan SBI terhadap perubahan suku bunga deposito, perubahan dari persentase nilai tukar, perubahan dari persentase jumlah M1, perubahan dari persentase nilai PDB, dan perubahan dari persentase IHK. Oleh karena itu, IRF yang akan dibahas adalah masing-masing respon variabel DDEP, DLNKURS, DLNM1, DLNPDB, dan DLNIHK terhadap kejutan DSBI.

Response to Cholesky One S.D, Innovations + 2 S.E.

Response of DSBI to DSBI

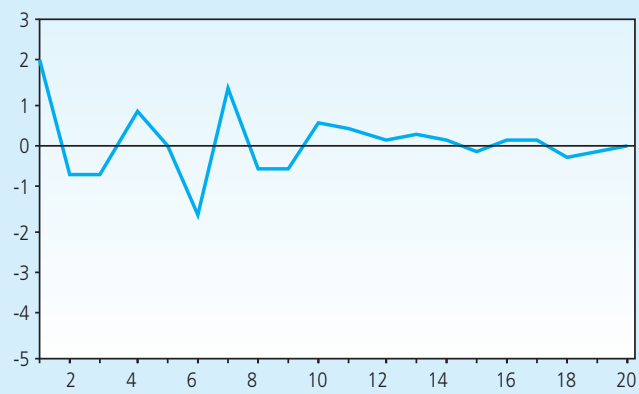

Response of DSBI to DDEP

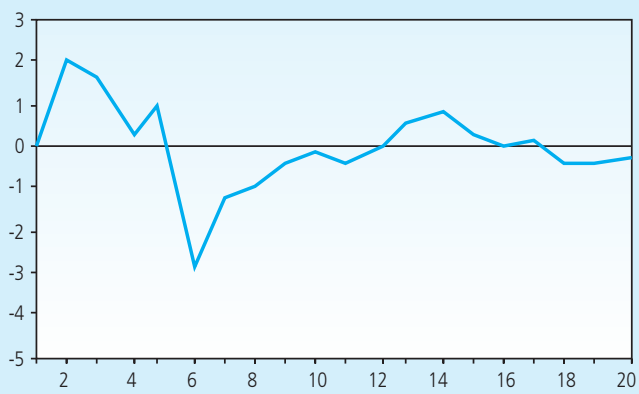

Grafik III.6. Impulse Response Function (IRF) 

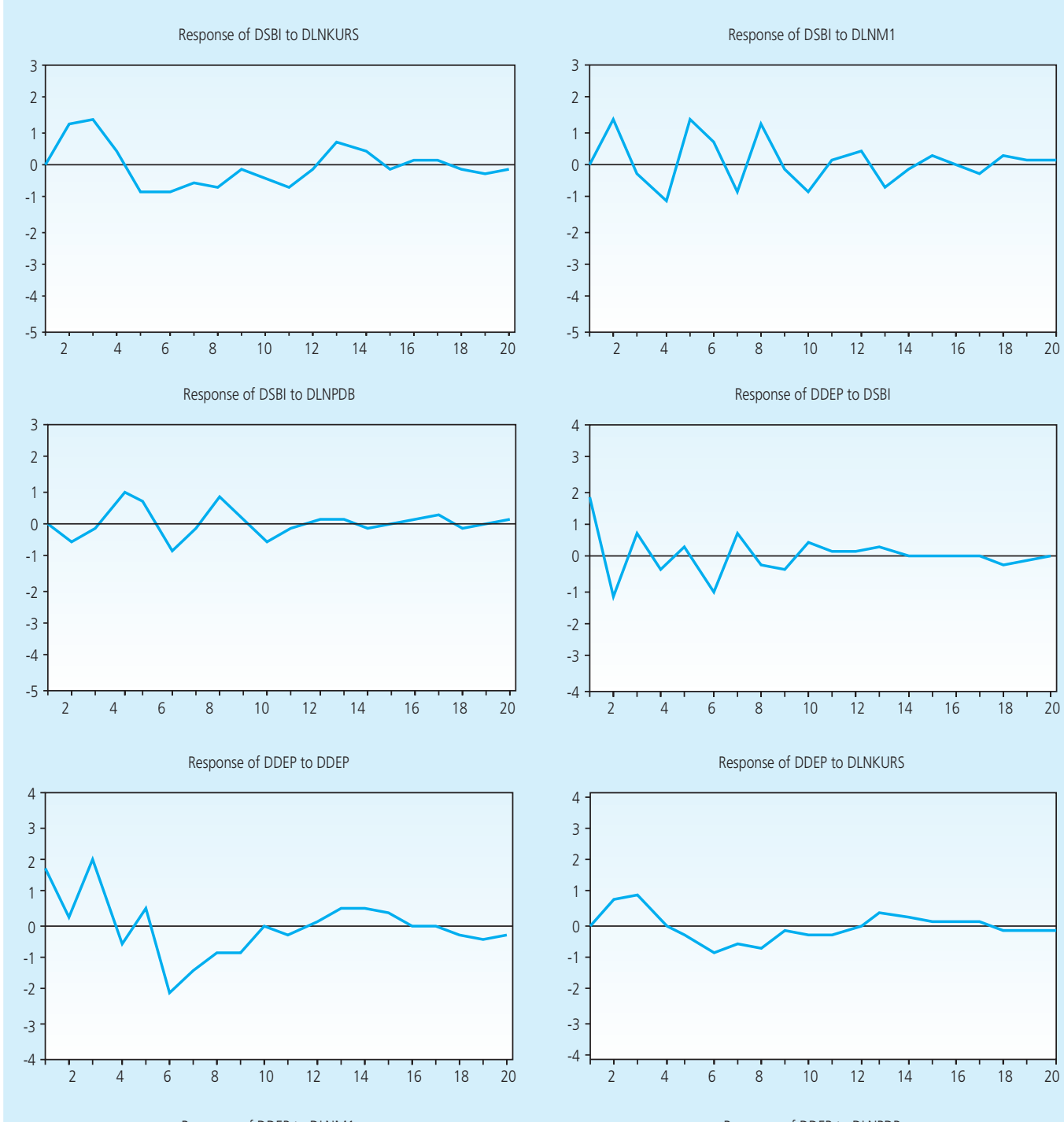

Response of DDEP to DLNM1

Response of DDEP to DLNPDB
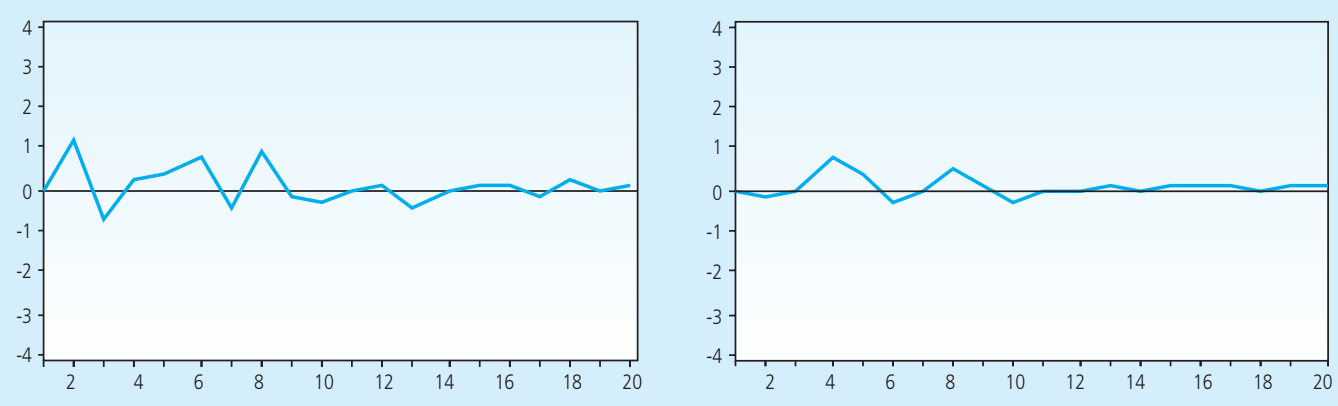

Grafik III.6. Impulse Response Function (IRF) (lanjutan) 

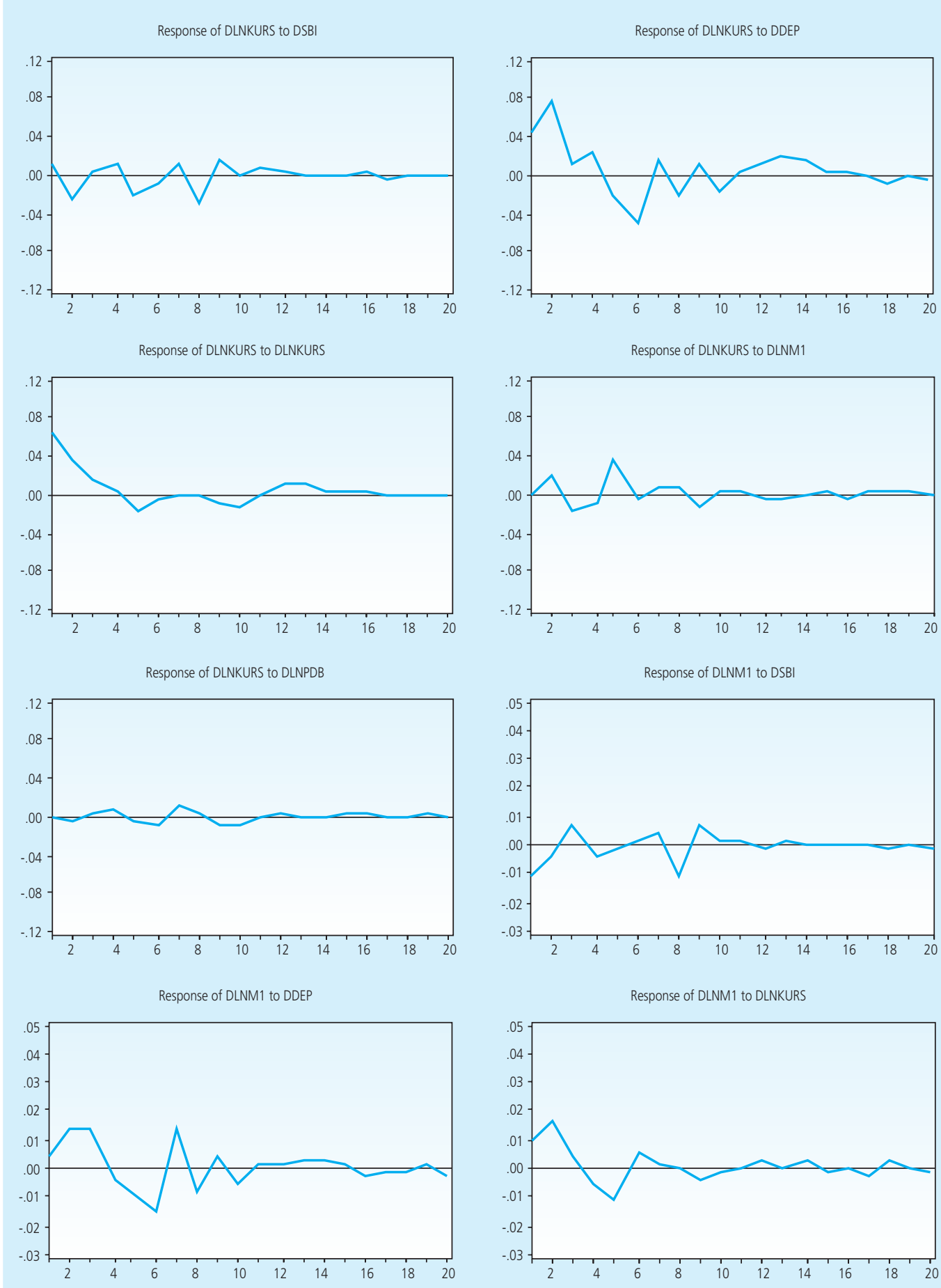

Grafik III.6. Impulse Response Function (IRF) (lanjutan) 

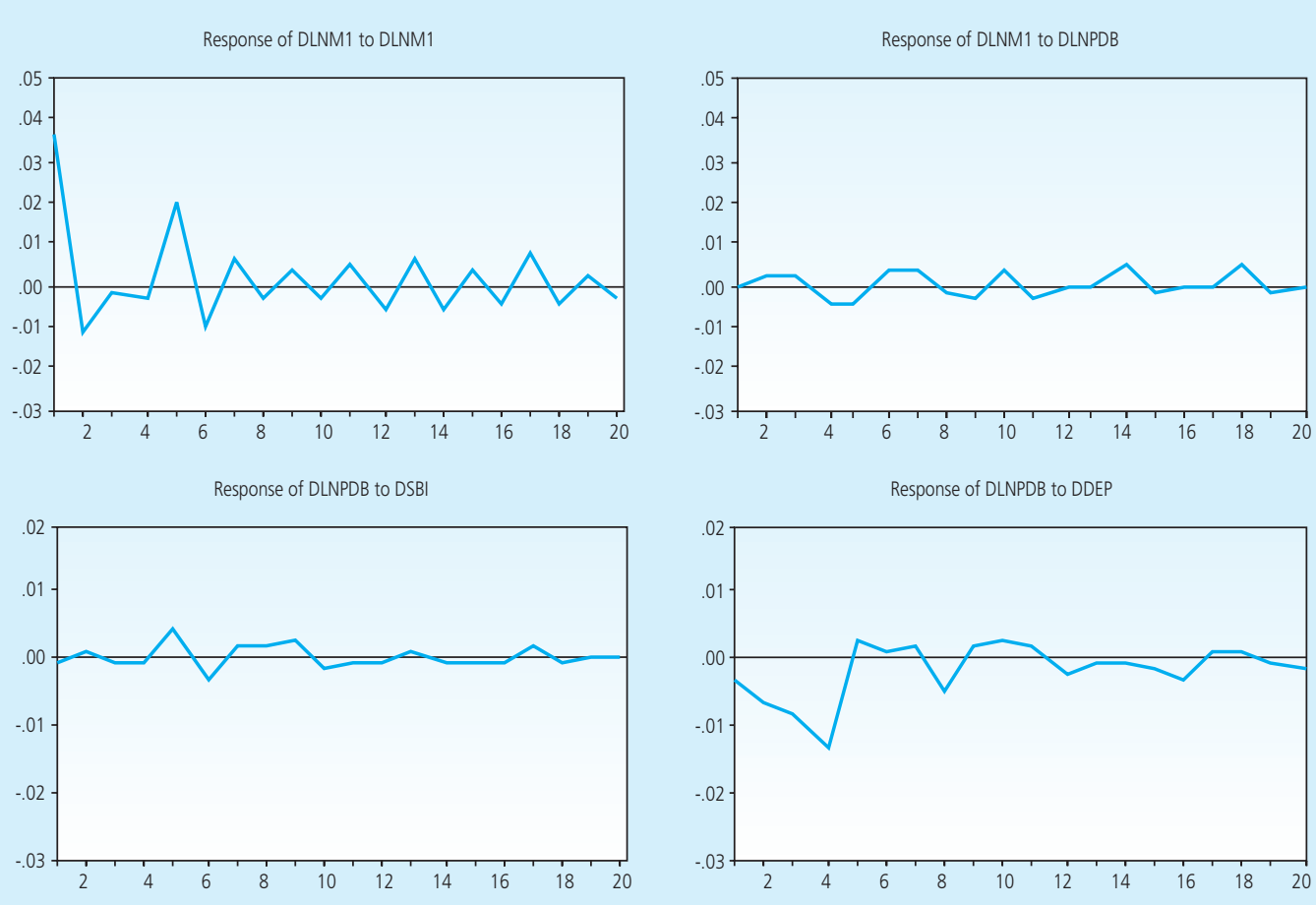

Response of DLNPDB to DLNKURS

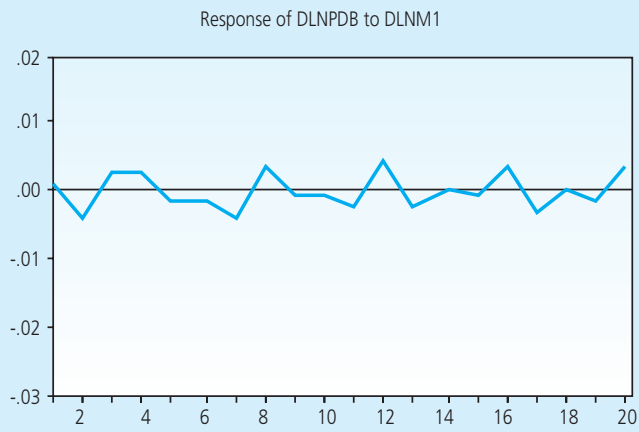

Response of DLNPDB to DLNPDB

Response of DLNIHK to DSBI
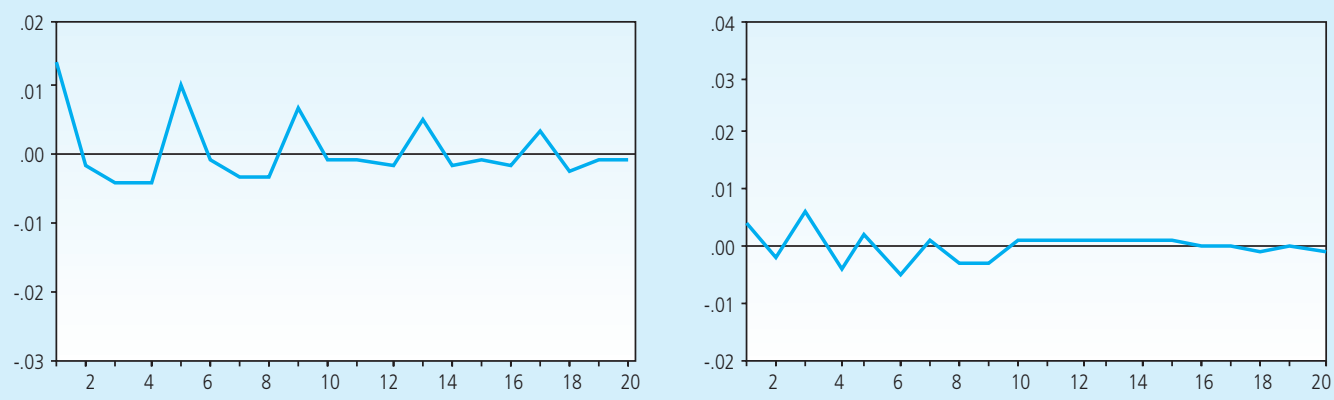

Grafik III.6. Impulse Response Function (IRF) (lanjutan) 

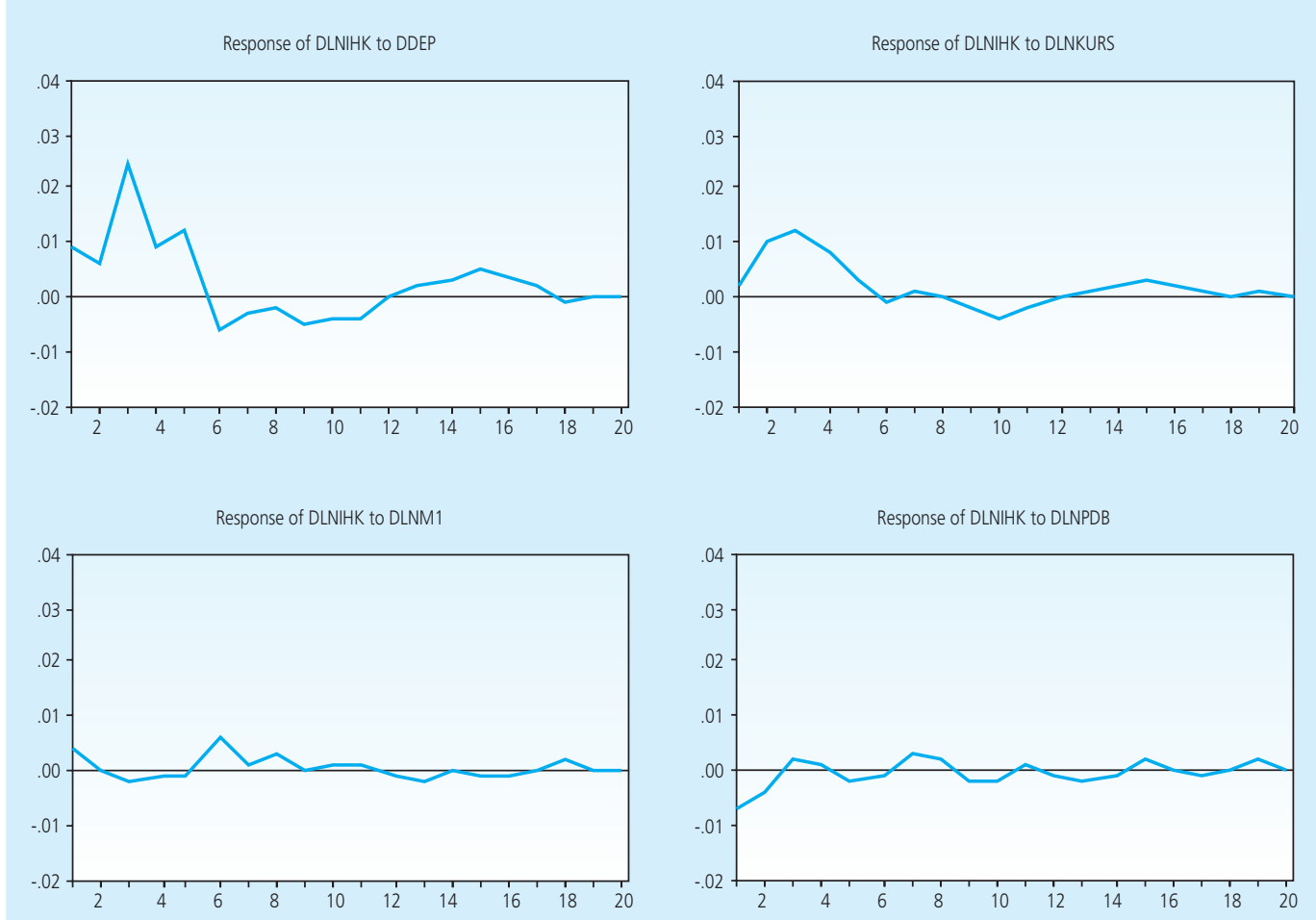

\section{Grafik III.6 \\ Impulse Response Function (IRF) (lanjutan)}

Grafik III.6 yang dihasilkan dapat menunjukkan respon variabel makroekonomi terhadap kejutan suku bunga SBI, yaitu respon positif atau negatif. Jika grafik IRF berada di atas titik keseimbangan maka respon variabel yang dianalisis adalah positif atau mengalami peningkatan. Namun, jika grafik IRF berada di bawah titik keseimbangan maka variabel yang dianalisis memberikan respon negatif atau mengalami penurunan. Selain itu, jika grafik IRF menunjukkan pergerakan yang makin mendekati titik keseimbangan atau kembali ke keseimbangan sebelumnya berarti bahwa respon suatu variabel akibat suatu kejutan makin lama akan menghilang sehingga kejutan tersebut tidak meninggalkan pengaruh permanen terhadap variabel tersebut.

Grafik III.6 yang menunjukkan respon variabel perubahan suku bunga deposito (DDEP) terhadap kejutan perubahan suku bunga SBI (DSBI) bergerak fluktuatif di sekitar garis keseimbangan dari triwulan pertama hingga ke-10. Selain itu, respon perubahan suku bunga deposito terhadap kejutan perubahan suku bunga SBI bernilai positif dan negatif secara 
bergantian pada rentang periode tersebut. Adanya kejutan perubahan suku bunga SBI mengakibatkan peningkatan perubahan suku bunga deposito pada triwulan pertama sehingga mencapai titik tertinggi. Setelah itu, perubahan suku bunga deposito tersebut mengalami penurunan pada triwulan ke-2 hingga mencapai titik terendah. Kemudian, pada triwulan ke11 hingga ke-20 grafik IRF bergerak mendekati garis keseimbangan. Secara umum dapat dinyatakan bahwa respon perubahan suku bunga deposito akibat kejutan perubahan suku bunga SBI hanya bersifat sementara pada jangka pendek dan menengah. Namun, respon tersebut akan menghilang pada jangka panjang.

Variabel perubahan persentase nilai tukar (DLNKURS) juga memberikan respon yang fluktuatif terhadap kejutan perubahan suku bunga SBI sebesar satu standar deviasi pada jangka pendek dan menengah. Pada triwulan ke-8, perubahan persentase nilai tukar mencapai titik terendah sebagai dampak dari kejutan perubahan suku bunga SBI. Respon tersebut bernilai fluktuatif antara respon positif dan negatif hingga triwulan ke-9. Setelah triwulan ke-9 tersebut, respon perubahan persentase nilai tukar tersebut bergerak dekat pada garis keseimbangan dan mendekati garis keseimbangan tersebut. Oleh karena itu, kejutan perubahan suku bunga SBI akan menghilang dan tidak permanen dalam jangka panjang.

Sementara itu, respon variabel perubahan persentase jumlah M1 (DLNM1) juga berfluktuasi terhadap kejutan suku bunga SBI selama periode pengamatan. Pada triwulan pertama, kejutan perubahan suku bunga SBI direspon secara negatif oleh perubahan persentase jumlah M1. Kemudian, respon tersebut mengalami fluktuasi pada periode selanjutnya. Kejutan perubahan suku bunga SBI mengakibatkan perubahan persentase jumlah M1 mencapai titik terendah pada triwulan pertama dan ke-8. Sementara, perubahan tertinggi terjadi pada triwulan ke-3 dan ke-9. Respon perubahan persentase jumlah M1 bergerak di sekitar garis keseimbangan hingga triwulan ke-9. Setelah triwulan ke-9 tersebut, pergerakan respon perubahan persentase jumlah M1 sangat dekat dengan garis keseimbangan. Keadaan ini menunjukkan bahwa kejutan suku bunga SBI tidak meninggalkan dampak permanen terhadap perubahan persentase jumlah M1 tersebut.

Secara umum, variabel perubahan persentase nilai PDB (DLNPDB) memberikan respon yang berfluktuasi lebih kecil terhadap kejutan perubahan suku bunga SBI dibanding variabel analisis lainnya. Grafik III.6 menunjukkan bahwa respon perubahan persentase nilai PDB pada awalnya bergerak dekat di sekitar garis keseimbangan. Kejutan perubahan suku bunga SBI mengakibatkan perubahan tertinggi persentase nilai PDB pada triwulan ke-5 dan perubahan terendah pada triwulan ke-6. Respon tersebut berfluktuasi hanya pada jangka pendek. Kemudian, respon perubahan persentase nilai PDB bergerak mendekati garis keseimbangan sehingga dampak kejutan perubahan suku bunga SBI tersebut akan hilang dalam jangka panjang. 
Perubahan persentase nilai PDB memberikan respon terhadap kejutan perubahan suku bunga SBI hanya pada jangka pendek dan menengah.

Tidak jauh berbeda dengan variabel analisis lainnya, grafik III.6 juga menunjukkan bahwa respon variabel perubahan persentase nilai IHK (DLNIHK) mengalami fluktuasi dalam jangka pendek dan menengah, yaitu hingga triwulan ke-7. Walaupun respon perubahan persentase nilai IHK berfluktuasi, namun respon tersebut lebih banyak bernilai negatif. Sebagai akibat respon perubahan persentase nilai IHK terhadap kejutan perubahan suku bunga SBI, perubahan persentase nilai IHK mencapai titik tertinggi pada triwulan ke-3 dan titik terendah pada triwulan ke-6. Kemudian, respon perubahan persentase nilai IHK bergerak sangat dekat di sekitar garis keseimbangan dan mendekati garis keseimbangan pada jangka panjang. Kenyataan dari grafik III.6 tersebut menyatakan bahwa pengaruh kejutan perubahan suku bunga SBI tersebut tidak permanen terhadap perubahan persentase nilai IHK.

\section{IV.2.5. Forecast Error Variance Decomposition (FEVD)}

Seperti IRF, hasil FEVD yang akan dibahas dalam penelitian ini hanya mencakup hasil FEVD yang berkaitan dengan tujuan penelitian. Nilai FEVD tiap variabel terhadap kejutan variabel DSBI dirangkum dalam tabel berikut.

\begin{tabular}{|c|c|c|c|c|c|c|}
\hline \multicolumn{7}{|c|}{ Tabel 4.5} \\
\hline $\begin{array}{c}\text { Response: } \\
\text { Impulse: } \\
\text { Periode }\end{array}$ & $\begin{array}{l}\text { DSBI } \\
\text { DSBI }\end{array}$ & $\begin{array}{l}\text { DDEP } \\
\text { DSBI }\end{array}$ & $\begin{array}{c}\text { DLNKURS } \\
\text { DSBI }\end{array}$ & $\begin{array}{c}\text { DLNM1 } \\
\text { DSBI }\end{array}$ & $\begin{array}{l}\text { DLNPDB } \\
\text { DSBI }\end{array}$ & $\begin{array}{c}\text { DLNIHK } \\
\text { DSBI }\end{array}$ \\
\hline 2 & 35.71894 & 47.94391 & 5.897142 & 6.109387 & 0.614492 & 3.779815 \\
\hline 4 & 23.28329 & 29.14783 & 5.637095 & 8.017953 & 0.339046 & 4.799320 \\
\hline 6 & 20.04875 & 25.30385 & 6.726678 & 5.579514 & 4.052438 & 5.698409 \\
\hline 8 & 20.24717 & 22.28275 & 9.637108 & 8.366168 & 4.163382 & 6.267271 \\
\hline 10 & 20.26201 & 21.71849 & 10.04675 & 9.028638 & 4.735793 & 6.546011 \\
\hline 12 & 20.18388 & 21.59651 & 10.12627 & 8.925709 & 4.436636 & 6.446060 \\
\hline 14 & 19.46703 & 21.02802 & 9.828850 & 8.667030 & 4.492983 & 6.395271 \\
\hline 16 & 19.24196 & 20.77073 & 9.770487 & 8.576414 & 4.342296 & 6.272895 \\
\hline 18 & 19.22685 & 20.68569 & 9.832097 & 8.357557 & 4.422248 & 6.253619 \\
\hline 20 & 19.11197 & 20.52099 & 9.815695 & 8.304606 & 4.314305 & 6.274154 \\
\hline
\end{tabular}

Pada variabel perubahan suku bunga deposito (DDEP), variasi terbesar pada triwulan ke3 hingga ke-20 disebabkan oleh kejutan dari variabel itu sendiri. Sementara, variasi terbesar pada triwulan pertama dan ke-2 disebabkan oleh kejutan variabel perubahan suku bunga SBI 
(DSBI), yaitu sebesar 53,73 dan 47,94 persen. Dampak kejutan perubahan suku bunga SBI terhadap variasi perubahan suku bunga deposito mengalami penurunan selama 20 triwulan periode pengamatan. Namun, kejutan perubahan suku bunga SBI tersebut tetap memberikan dampak yang cukup besar selama periode pengamatan. Pada triwulan pertama dan ke-2, kejutan perubahan suku bunga SBI merupakan penjelas terbesar pertama variasi perubahan suku bunga deposito. Kemudian, pada triwulan ke-3 hingga ke-20 kejutan perubahan suku bunga SBI merupakan penjelas terbesar ke-2 variasi perubahan suku bunga deposito. Pada periode akhir pengamatan, kejutan perubahan suku bunga SBI mempengaruhi 20,52\% variasi perubahan suku bunga deposito.

Hasil nilai FEVD tersebut menunjukkan bahwa kejutan dari perubahan suku bunga SBI memiliki pengaruh yang besar terhadap variasi perubahan suku bunga deposito hanya pada dua triwulan awal setelah kejutan. Setelah melewati triwulan ke-2, pengaruh kejutan perubahan suku bunga SBI mengalami penurunan hingga triwulan ke-20. Namun, kejutan perubahan suku bunga SBI setelah triwulan ke-2 tetap memiliki pengaruh yang cukup besar terhadap variasi perubahan suku bunga deposito. Hal ini memiliki implikasi bahwa penerapan kebijakan moneter melalui perubahan suku bunga SBI efektif menjelaskan variasi perubahan suku bunga deposito. Bahkan, perubahan suku bunga SBI tersebut sangat efektif menjelaskan variasi perubahan suku bunga deposito pada jangka pendek.

Variasi terbesar variabel perubahan persentase nilai tukar (DLNKURS) juga dijelaskan oleh kejutan dari variabel itu sendiri pada triwulan pertama pengamatan, yaitu sebesar 66,42 persen. Kemudian, kejutan dari variabel itu sendiri merupakan penjelas terbesar kedua variasinya pada triwulan ke-2 hingga ke-20. Sementara, sejak triwulan ke-2 hingga ke-20 variasi terbesar lebih disebabkan oleh perubahan suku bunga deposito. Variasi perubahan persentase nilai tukar yang disebabkan oleh kejutan perubahan suku bunga deposito adalah sebesar 52,17\% pada triwulan ke-2. Secara umum, nilai tersebut mengalami sedikit penurunan hingga menjadi sebesar $46 \%$ pada periode ke-20.

Secara umum, pengaruh kejutan perubahan suku bunga SBI terhadap variasi perubahan persentase nilai tukar mengalami peningkatan dari periode pengamatan pertama hingga ke10 dan kemudian mengalami penurunan lagi hingga periode ke-20. Kejutan perubahan suku bunga SBI hanya memberikan pengaruh yang kecil terhadap variasi perubahan persentase nilai tukar. Kejutan perubahan suku bunga SBI hanya mampu menjadi penjelas keempat variasi perubahan persentase nilai tukar selama periode pengamatan. Pada triwulan pertama, kejutan perubahan suku bunga SBI menjelaskan 2,35\% variasi perubahan persentase nilai tukar. Pada triwulan ke-20, pengaruh kejutan perubahan suku bunga SBI tersebut menjadi sebesar 9,82 persen. 
Hasil dari nilai FEVD tersebut menyatakan bahwa variasi perubahan persentase nilai tukar tidak dapat dikendalikan secara cepat oleh kebijakan moneter melalui perubahan suku bunga SBI. Perubahan suku bunga SBI tidak dapat langsung memberikan pengaruh terhadap variasi perubahan persentase nilai tukar, melainkan harus menunggu selama sembilan triwulan setelah perubahan suku bunga SBI agar dampak perubahan suku bunga tersebut dapat mempengaruhi variasi perubahan persentase nilai tukar lebih dari 10 persen. Namun, nilai pengaruh tersebut mengalami penurunan kembali setelah melewati triwulan ke-10.

Variasi variabel perubahan persentase jumlah M1 (DLNM1) terbesar disebabkan oleh kejutan variabel itu sendiri selama 20 periode pengamatan. Namun, nilai pengaruh kejutan tersebut mengalami penurunan hingga triwulan ke-11 dan kemudian mengalami peningkatan hingga triwulan ke-20. Pada triwulan pertama, sebesar 85,5\% variasi perubahan persentase jumlah M1 dijelaskan oleh kejutan dari variabel itu sendiri. Selain kejutan dari variabel itu sendiri, variasi perubahan persentase jumlah M1 juga disebabkan oleh kejutan perubahan suku bunga deposito dan perubahan persentase nilai tukar.

Sementara itu, kejutan perubahan suku bunga SBI memberikan pengaruh yang kecil pada variasi perubahan persentase jumlah M1. Walaupun secara umum nilai pengaruhnya mengalami fluktuasi yang kecil selama 20 periode pengamatan, pengaruh kejutan perubahan suku bunga SBI hanya mampu menjadi penjelas ke-4 dan ke-5 variasi perubahan persentase jumlah M1. Pada triwulan pertama, kejutan perubahan suku bunga SBI hanya mampu menjelaskan variasi perubahan persentase jumlah M1 sebesar 7,84 persen. Pada triwulan ke20 , pengaruh kejutan perubahan suku bunga SBI menjadi sebesar $8,3 \%$ variasi perubahan persentase jumlah $\mathrm{M} 1$.

Penjelasan mengenai variasi perubahan persentase jumlah M1 tersebut menyatakan bahwa kebijakan moneter melalui perubahan suku bunga SBI tidak langsung direspon oleh perubahan persentase jumlah uang beredar. Pengaruh perubahan suku bunga SBI tersebut bernilai kecil dalam menjelaskan variasi perubahan persentase jumlah uang beredar, baik pada jangka pendek maupun jangka panjang. Keadaan ini memberikan kesimpulan bahwa perubahan suku bunga SBI kurang efektif dalam mempengaruhi perubahan persentase jumlah uang beredar.

Variasi perubahan persentase nilai PDB (DLNPDB) lebih besar dijelaskan oleh kejutan dari variabel itu sendiri selama periode pengamatan. Pada triwulan pertama, kejutan dari variabel tersebut menjelaskan sebesar 92,85\% variasi variabel itu sendiri. Nilai tersebut secara umum mengalami penurunan hingga pada triwulan ke-20 menjadi sebesar 34,62 persen. Kejutan variabel lain yang juga besar pengaruhnya terhadap variasi perubahan persentase nilai PDB berasal dari perubahan suku bunga deposito dan perubahan persentase nilai tukar. 
Sementara itu, kejutan perubahan suku bunga SBI sangat kecil menjelaskan variasi perubahan persentase nilai PDB. Bahkan, hingga akhir periode pengamatan kejutan perubahan suku bunga SBI hanya menjadi penjelas terkecil variasi perubahan persentase nilai PDB. Pada triwulan pertama, kejutan perubahan suku bunga SBI hanya mampu menjelaskan 0,1\% variasi perubahan persentase nilai PDB. Nilai pengaruh tersebut secara umum mengalami peningkatan selama periode pengamatan. Selama triwulan pertama hingga ke-4, pengaruh kejutan perubahan suku bunga SBI sangat kecil dalam menjelaskan variasi perubahan persentase nilai PDB, yaitu sekitar 0,1 - 0,61 persen. Namun, selama triwulan ke-6 hingga ke-20, nilai pengaruh tersebut hanya menjelaskan 4,05-4,74\% dari variasi perubahan persentase nilai PDB.

Keadaan yang ditunjukkan respon perubahan persentase nilai PDB terhadap kejutan suku bunga SBI menyatakan bahwa perubahan suku bunga SBI memiliki pengaruh yang sangat kecil terhadap variasi perubahan persentase nilai PDB. Pengaruh perubahan suku bunga yang kecil tersebut terjadi hingga periode jangka panjang. Perubahan suku bunga SBI tersebut harus menunggu selama enam triwulan agar perubahan tersebut mampu menjelaskan sebesar 4,05\% variasi perubahan persentase nilai PDB. Bahkan, setelah menunggu selama 20 triwulan sejak terjadi perubahan suku bunga SBI tersebut, variasi perubahan persentase nilai PDB yang mampu dipengaruhi hanya sebesar 4,31 persen. Hal ini memberikan kesimpulan bahwa perubahan suku bunga SBI tidak efektif dalam mentransmisikan kebijakan moneter terhadap perubahan persentase nilai PDB.

Seperti variabel lainnya dalam penelitian ini secara umum, variasi terbesar variabel perubahan persentase nilai IHK (DLNIHK) juga disebabkan oleh kejutan dari variabel itu sendiri pada dua periode awal pengamatan. Secara umum, kemampuan kejutan itu sendiri dalam menjelaskan variasinya juga mengalami penurunan selama 20 periode pengamatan. Variasi perubahan persentase nilai IHK juga dijelaskan cukup besar oleh kejutan dari perubahan suku bunga deposito dan perubahan persentase nilai tukar. Kejutan perubahan suku bunga deposito merupakan penjelas terbesar pertama variasi perubahan persentase nilai IHK setelah triwulan ke-2.

Sementara itu, kemampuan kejutan perubahan suku bunga SBI dalam menjelaskan variasi perubahan persentase nilai IHK mengalami peningkatan hingga triwulan ke-9 dan kemudian mengalami penurunan yang kecil hingga triwulan ke-20. Namun, kejutan perubahan suku bunga SBI tersebut tidak memberi pengaruh yang besar. Pada triwulan pertama, kejutan perubahan suku bunga SBI mampu menjelaskan variasi perubahan persentase nilai IHK sebesar 4,17 persen. Setelah triwulan ke-8, kejutan perubahan suku bunga SBI tersebut mampu menjelaskan sekitar $6 \%$ variasi perubahan persentase nilai IHK. Nilai pengaruh kejutan tersebut hanya mampu menjadi penjelas ke-4 dari variasi perubahan persentase nilai IHK. 
Keadaan yang ditunjukkan oleh respon perubahan persentase nilai IHK terhadap kejutan perubahan suku bunga SBI tersebut menyatakan bahwa perubahan suku bunga SBI tidak secara cepat direspon oleh perubahan persentase nilai IHK. Selain itu, pengaruhnya juga bernilai kecil terhadap perubahan persentase nilai IHK. Perubahan suku bunga SBI harus menunggu hingga triwulan ke-6 agar kejutan dari perubahan suku bunga SBI tersebut menjadi penjelas ke-4 variasi perubahan persentase nilai IHK. Bahkan, setelah menunggu selama 20 triwulan sejak perubahan suku bunga SBI, kejutan dari perubahan suku bunga SBI hanya mampu menjelaskan variasi perubahan persentase nilai IHK sebesar 6,27 persen. Hal ini menunjukkan bahwa perubahan suku bunga SBI kurang efektif dalam mempengaruhi variasi perubahan persentase nilai IHK.

\section{KESIMPULAN DAN SARAN}

Dari hasil analisis yang telah diperoleh maka kesimpulan dan saran penelitian ini akan diuraikan sebagai berikut.

\section{V.1. Kesimpulan}

Berdasarkan analisis Impulse Response Function (IRF) dan Forecast Error Variance Decomposition (FEVD) yang telah dilakukan maka diperoleh kesimpulan sebagai berikut.

1. Dari hasil analisis IRF ditemukan bahwa perubahan suku bunga deposito, perubahan persentase nilai tukar, perubahan persentase jumlah uang beredar, perubahan persentase nilai PDB, dan perubahan persentase nilai IHK memberikan respon terhadap kejutan perubahan suku bunga SBI dalam jangka pendek. Dalam jangka panjang, pengaruh kejutan dari perubahan suku bunga SBI tidak bersifat permanen terhadap semua variabel analisis tersebut, melainkan akan menghilang dan tidak lagi mempengaruhi respon variabel-variabel tersebut.

2. Dari hasil nilai FEVD dapat dinyatakan bahwa kejutan perubahan suku bunga SBI menjadi penjelas terbesar fluktuasi perubahan suku bunga deposito dalam jangka pendek. Dampak kejutan perubahan suku bunga SBI terhadap fluktuasi perubahan suku bunga deposito dalam jangka panjang semakin menurun namun tetap memberikan pengaruh yang besar. Sementara itu, pengaruh kejutan perubahan suku bunga SBI terhadap variasi perubahan persentase nilai tukar, perubahan persentase jumlah uang beredar, perubahan persentase nilai PDB, dan perubahan persentase nilai IHK secara umum mengalami peningkatan selama periode pengamatan. Pada jangka pendek, kejutan perubahan suku bunga SBI memberikan pengaruh yang kecil dalam menjelaskan variasi perubahan persentase nilai tukar, perubahan persentase jumlah uang beredar, dan perubahan persentase nilai IHK. Namun, pada jangka panjang kemampuan kejutan tersebut semakin meningkat. Sementara itu, variasi perubahan 
persentase nilai PDB sangat kecil dijelaskan oleh kejutan perubahan suku bunga SBI, baik pada jangka pendek maupun pada jangka panjang.

3. Secara umum, kejutan perubahan suku bunga SBI memberikan pengaruh yang besar terhadap variasi perubahan suku bunga deposito. Sementara itu, kejutan perubahan suku bunga SBI memiliki kemampuan yang kecil dan butuh waktu yang lama dalam mempengaruhi variasi variabel analisis lainnya. Namun, variasi variabel analisis lainnya cukup besar dijelaskan oleh kejutan perubahan suku bunga deposito. Hal ini mengindikasikan bahwa perubahan suku bunga SBI dapat memberikan pengaruh secara tidak langsung pada variabel makroekonomi lainnya, yaitu melalui perubahan suku bunga deposito.

\section{V.2. Saran}

Berdasarkan hasil analisis dan kesimpulan yang diperoleh, maka terdapat beberapa saran yang dapat dirumuskan sebagai berikut.

1. Walaupun kejutan dari perubahan suku bunga SBI tidak bersifat permanen dalam jangka panjang, namun tetap perlu kehati-hatian dalam mengambil keputusan mengenai penerapan kebijakan moneter melalui perubahan suku bunga SBI. Hal ini diperlukan karena pengaruh kejutan perubahan suku bunga SBI direspon oleh variasi perubahan variabel makroekonomi pada jangka pendek dan menengah.

2. Efektivitas pengaruh penerapan kebijakan moneter melalui perubahan suku SBI terhadap sektor perbankan perlu semakin ditingkatkan sehingga kemampuan kejutan suku bunga SBI semakin besar mempengaruhi variasi perubahan suku bunga deposito pada jangka pendek dan jangka panjang. Hal tersebut dimaksudkan agar kejutan perubahan suku bunga SBI dapat lebih besar mempengaruhi variabel makroekonomi lainnya melalui sektor perbankan, yaitu melalui perubahan suku bunga deposito.

3. Pihak otoritas moneter perlu mulai mempertimbangkan dan menganalisis peran sasaran operasional lainnya, misalnya suku bunga PUAB, dalam mentransmisikan kebijakan moneter terhadap variabel makroekonomi Indonesia. 


\section{Daftar Pustaka}

Arif, M. M. dan A. Tohari, (2006), "Peranan Kebijakan Moneter Dalam Menjaga Stabilitas Perekonomian Indonesia Sebagai Respon Terhadap Fluktuasi Perekonomian Dunia", Buletin Ekonomi Moneter dan Perbankan. Oktober, Vol. 9 (2): 145 - 177.

Bank Indonesia, Statistik Ekonomi dan Keuangan Indonesia (SEKI), Berbagai Terbitan. Laporan Tahunan Perekonomian Indonesia, Berbagai Terbitan.

Bernanke, B. S. dan I. Mihov, (1998), "Measuring Monetary Policy", The Quarterly Journal of Economics, Agustus, Vol. 113 (3): 869 - 902.

Cheng, K. C., (2006), "A VAR Analysis of Kenya's Monetary Policy Transmission Mechanism: How Does the Central Bank's REPO Rate Affect the Economy?", IMF Working Paper, Desember, No.300: 1 - 26.

Dabla-Norris, E. dan H. Floerkemeier, (2006), "Transmission Mechanisms of Monetary Policy in Armenia: Evidence from VAR Analysis", IMF Working Paper, November, No.248: 1 - 27.

Enders, W., (1995), Applied Econometric Time Series, New York: Jhon Wiley \& Sons.

Eviews 4 User's Guide, (2002), Quantitative Micro Software, LLC, Bab 20: 519 - 550.

Fung, B. S. C., (2002), "A VAR Analysis of the Effects of Monetary Policy in East Asia", BIS Working Paper, No.119.

Gujarati, D. N., (2003), Basic Econometrics, Fourth Edition, Singapore: McGraw-Hill. Haryono, E., W. A. Nugroho dan W. Pratomo, (2000), "Mekanisme Pengendalian Moneter Dengan Inflasi Sebagai Sasaran Tunggal", Buletin Ekonomi Moneter dan Perbankan, Maret, Vol 1(1): $73-74$.

International Monetary Fund, International Financial Statistics, Berbagai Terbitan. Julaihah, U. dan Insukindro, (2004), "Analisis Dampak Kebijakan Moneter Terhadap Variabel Makroekonomi di Indonesia Tahun 1983.1 - 2003.2", Buletin Ekonomi Moneter dan Perbankan, September, Vol. 7 (2): 323 - 341.

Kharie, L., (2006), “Hubungan Kausal Dinamis Antara Variabel-Variabel Moneter Utama dan

Output: Kasus Indonesia di Bawah Sistem Nilai Tukar Mengambang dan Mengambang Terkendali", Buletin Ekonomi Moneter dan Perbankan, Juni, Vol. 9 (1): 75 - 112.

Kuijs, L., (2002), "Monetary Policy Transmission Mechanisms and Inflation in The Slovak Republic", IMF Working Paper, Mei, No.80: 1 - 26.

Nuryati, Y., H. Siregar dan A. Ratnawati, (2006), "Dampak Kebijakan Inflation Targeting Terhadap Beberapa Variabel Makroekonomi di Indonesia", Buletin Ekonomi Moneter dan Perbankan, Juni, Vol. 9 (1): 113 - 134. 
Pusat Pendidikan dan Studi Kebanksentralan (PPSK), Materi Kebijakan Moneter di Indonesia, Training For Trainers Kebanksentralan, Bank Indonesia, Jakarta.

Simorangkir, I. dan Suseno, (2004), Sistem dan Kebijakan Nilai Tukar, Pusat Pendidikan dan Studi Kebanksentralan (PPSK), Bank Indonesia, Jakarta.

Solikin, (2005), "Analisis Kebijakan Moneter Dalam Model Makroekonometrik Struktural Jangka

Panjang: Structural Cointegrating Vector Autoregression", Buletin Ekonomi Moneter dan Perbankan, September, Vol. 8 (2): 191 - 229.

Warjiyo, P., (2004), Mekanisme Transmisi Kebijakan Moneter di Indonesia, Pusat Pendidikan dan Studi Kebanksentralan (PPSK), Bank Indonesia, Jakarta.

dan D. Zulverdi, (1998), "Penggunaan Suku Bunga Sebagai Sasaran Operasional

Kebijakan Moneter di Indonesia", Buletin Ekonomi Moneter dan Perbankan, Juli, Vol. 1 (1): 25-58.

dkk, (2003), Bank Indonesia: Bank sentral Republik Indonesia Tinjauan,

Kelembagaan, Kebijakan, dan Organisasi, Pusat Pendidikan dan Studi Kebanksentralan (PPSK),

Bank Indonesia, Jakarta.

www.bi.go.id 
LAMPIRAN : Sistem DVAR

\begin{tabular}{|c|c|c|c|c|c|c|}
\hline \multicolumn{7}{|c|}{$\begin{array}{l}\text { Vector Autoregression Estimates } \\
\text { Sample(adjusted): 1991:2 2007:4 } \\
\text { Included observations: } 67 \text { after adjusting endpoints } \\
\text { Standard errors in ( ) \& t-statistics in [ ] }\end{array}$} \\
\hline & DSBI & DDEP & DLNKURS & DLNM1 & DLNPDB & DLNIHK \\
\hline DSBI(-1) & $\begin{array}{r}-0.844849 \\
(0.21074) \\
{[-4.00904]}\end{array}$ & $\begin{array}{r}-0.359927 \\
(0.27599) \\
{[-1.30414]}\end{array}$ & $\begin{array}{r}-0.045693 \\
(0.00871) \\
{[-5.24663]}\end{array}$ & $\begin{array}{r}-0.006392 \\
(0.00415) \\
{[-1.53930]}\end{array}$ & $\begin{array}{r}0.002603 \\
(0.00157) \\
{[1.65938]}\end{array}$ & $\begin{array}{r}-0.001391 \\
(0.00201) \\
{[-0.69039]}\end{array}$ \\
\hline DSBI(-2) & $\begin{array}{r}-0.575955 \\
(0.30884) \\
{[-1.86487]}\end{array}$ & $\begin{array}{r}-0.372007 \\
(0.40447) \\
{[-0.91973]}\end{array}$ & $\begin{array}{r}-0.008846 \\
(0.01276) \\
{[-0.69308]}\end{array}$ & $\begin{array}{r}0.002126 \\
(0.00609) \\
{[0.34930]}\end{array}$ & $\begin{array}{r}0.001864 \\
(0.00230) \\
{[0.81063]}\end{array}$ & $\begin{array}{r}-0.001887 \\
(0.00295) \\
{[-0.63901]}\end{array}$ \\
\hline DSBII-3) & $\begin{array}{r}0.243039 \\
(0.26344) \\
{[0.92258]}\end{array}$ & $\begin{array}{c}0.250963 \\
(0.34500) \\
{[0.72742]}\end{array}$ & $\begin{array}{r}-0.014108 \\
(0.01089) \\
{[-1.29585]}\end{array}$ & $\begin{array}{r}-0.000172 \\
(0.00519) \\
{[-0.03315]}\end{array}$ & $\begin{array}{r}0.003631 \\
(0.00196) \\
{[1.85171]}\end{array}$ & $\begin{array}{r}0.000645 \\
(0.00252) \\
{[0.25590]}\end{array}$ \\
\hline DSBI(-4) & $\begin{array}{r}-0.162914 \\
(0.17156) \\
{[-0.94961]}\end{array}$ & $\begin{array}{r}0.155321 \\
(0.22468) \\
{[0.69130]}\end{array}$ & $\begin{array}{r}0.012350 \\
(0.00709) \\
{[1.74191]}\end{array}$ & $\begin{array}{r}0.003155 \\
(0.00338) \\
{[0.93319]}\end{array}$ & $\begin{array}{r}0.000425 \\
(0.00128) \\
{[0.33253]}\end{array}$ & $\begin{array}{r}0.001281 \\
(0.00164) \\
{[0.78094]}\end{array}$ \\
\hline $\operatorname{DDEP}(-1)$ & $\begin{array}{r}0.653539 \\
(0.21804) \\
{[2.99739]}\end{array}$ & $\begin{array}{r}-0.010297 \\
(0.28555) \\
{[-0.03606]}\end{array}$ & $\begin{array}{c}0.037712 \\
(0.00901) \\
{[4.18527]}\end{array}$ & $\begin{array}{r}0.001212 \\
(0.00430) \\
{[0.28215]}\end{array}$ & $\begin{array}{r}-0.002248 \\
(0.00162) \\
{[-1.38468]}\end{array}$ & $\begin{array}{r}1.71 \mathrm{E}-05 \\
(0.00208) \\
{[0.00821]}\end{array}$ \\
\hline $\operatorname{DDEP}(-2)$ & $\begin{array}{r}0.601701 \\
(0.31888) \\
{[1.88694]}\end{array}$ & $\begin{array}{r}0.788825 \\
(0.41761) \\
{[1.88890]}\end{array}$ & $\begin{array}{r}0.021011 \\
(0.01318) \\
{[1.59440]}\end{array}$ & $\begin{array}{r}0.001580 \\
(0.00628) \\
{[0.25142]}\end{array}$ & $\begin{array}{r}-0.002929 \\
(0.00237) \\
{[-1.23375]}\end{array}$ & $\begin{array}{r}0.005711 \\
(0.00305) \\
{[1.87339]}\end{array}$ \\
\hline $\operatorname{DDEP}(-3)$ & $\begin{array}{r}-0.221847 \\
(0.28408) \\
{[-0.78093]}\end{array}$ & $\begin{array}{r}-0.076583 \\
(0.37204) \\
{[-0.20585]}\end{array}$ & $\begin{array}{c}0.009397 \\
(0.01174) \\
{[0.80045]}\end{array}$ & $\begin{array}{r}-0.002251 \\
(0.00560) \\
{[-0.40212]}\end{array}$ & $\begin{array}{r}-0.002621 \\
(0.00211) \\
{[-1.23951]}\end{array}$ & $\begin{array}{r}-0.000392 \\
(0.00272) \\
{[-0.14445]}\end{array}$ \\
\hline $\operatorname{DDEP}(-4)$ & $\begin{array}{r}0.409691 \\
(0.20715) \\
{[1.97775]}\end{array}$ & $\begin{array}{r}-0.091059 \\
(0.27129) \\
{[-0.33565]}\end{array}$ & $\begin{array}{r}-0.010084 \\
(0.00856) \\
{[-1.17791]}\end{array}$ & $\begin{array}{r}-0.000642 \\
(0.00408) \\
{[-0.15739]}\end{array}$ & $\begin{array}{c}0.000598 \\
(0.00154) \\
{[0.38808]}\end{array}$ & $\begin{array}{r}-0.001720 \\
(0.00198) \\
{[-0.86825]}\end{array}$ \\
\hline DLNKURS(-1) & $\begin{array}{r}11.05186 \\
(4.58467) \\
{[2.41061]}\end{array}$ & $\begin{array}{r}6.892171 \\
(6.00424) \\
{[1.14788]}\end{array}$ & $\begin{array}{r}0.403562 \\
(0.18947) \\
{[2.12997]}\end{array}$ & $\begin{array}{r}0.296200 \\
(0.09034) \\
{[3.27860]}\end{array}$ & $\begin{array}{r}-0.043089 \\
(0.03413) \\
{[-1.26252]}\end{array}$ & $\begin{array}{r}0.138788 \\
(0.04383) \\
{[3.16625]}\end{array}$ \\
\hline DLNKURS(-2) & $\begin{array}{r}7.002194 \\
(5.11525) \\
{[1.36889]}\end{array}$ & $\begin{array}{r}9.802153 \\
(6.69910) \\
{[1.46320]}\end{array}$ & $\begin{array}{r}0.354119 \\
(0.21140) \\
{[1.67515]}\end{array}$ & $\begin{array}{r}0.119313 \\
(0.10080) \\
{[1.18368]}\end{array}$ & $\begin{array}{r}-0.100581 \\
(0.03808) \\
{[-2.64134]}\end{array}$ & $\begin{array}{r}0.161271 \\
(0.04891) \\
{[3.29753]}\end{array}$ \\
\hline
\end{tabular}




\begin{tabular}{|c|c|c|c|c|c|c|}
\hline \multicolumn{7}{|c|}{$\begin{array}{l}\text { Vector Autoregression Estimates } \\
\text { Sample(adjusted): 1991:2 2007:4 } \\
\text { Included observations: } 67 \text { after adjusting endpoints } \\
\text { Standard errors in ( ) \& t-statistics in [ ] }\end{array}$} \\
\hline & DSBI & DDEP & DLNKURS & DLNM1 & DLNPDB & DLNIHK \\
\hline DLNKURS(-3) & $\begin{array}{l}0.138589 \\
(5.48000) \\
{[0.02529]}\end{array}$ & $\begin{array}{c}0.905028 \\
(7.17680) \\
{[0.12610]}\end{array}$ & $\begin{array}{r}0.148824 \\
(0.22647) \\
{[0.65715]}\end{array}$ & $\begin{array}{r}-0.085971 \\
(0.10799) \\
{[-0.79613]}\end{array}$ & $\begin{array}{r}-0.086296 \\
(0.04079) \\
{[-2.11537]}\end{array}$ & $\begin{array}{r}0.071902 \\
(0.05239) \\
{[1.37233]}\end{array}$ \\
\hline DLNKURS(-4) & $\begin{array}{r}-7.465786 \\
(5.11490) \\
{[-1.45962]}\end{array}$ & $\begin{array}{r}-3.205248 \\
(6.69865) \\
{[-0.47849]}\end{array}$ & $\begin{array}{r}-0.055550 \\
(0.21138) \\
{[-0.26280]}\end{array}$ & $\begin{array}{r}-0.289320 \\
(0.10079) \\
{[-2.87047]}\end{array}$ & $\begin{array}{r}-0.003353 \\
(0.03808) \\
{[-0.08807]}\end{array}$ & $\begin{array}{r}-0.022527 \\
(0.04890) \\
{[-0.46064]}\end{array}$ \\
\hline DLNM1(-1) & $\begin{array}{r}38.58507 \\
(7.56185) \\
{[5.10260]}\end{array}$ & $\begin{array}{r}35.08496 \\
(9.90326) \\
{[3.54277]}\end{array}$ & $\begin{array}{l}0.719810 \\
(0.31251) \\
{[2.30335]}\end{array}$ & $\begin{array}{r}-0.326772 \\
(0.14901) \\
{[-2.19295]}\end{array}$ & $\begin{array}{r}-0.093612 \\
(0.05629) \\
{[-1.66296]}\end{array}$ & $\begin{array}{r}0.045307 \\
(0.07230) \\
{[0.62667]}\end{array}$ \\
\hline DLNM1(-2) & $\begin{array}{r}9.024668 \\
(9.83740) \\
{[0.91738]}\end{array}$ & $\begin{array}{r}5.767623 \\
(12.8834) \\
{[0.44768]}\end{array}$ & $\begin{array}{r}0.144235 \\
(0.40655) \\
{[0.35478]}\end{array}$ & $\begin{array}{r}-0.136796 \\
(0.19385) \\
{[-0.70567]}\end{array}$ & $\begin{array}{r}0.013375 \\
(0.07323) \\
{[0.18264]}\end{array}$ & $\begin{array}{r}-0.071888 \\
(0.09405) \\
{[-0.76432]}\end{array}$ \\
\hline DLNM1(-3) & $\begin{array}{r}-9.292726 \\
(9.45158) \\
{[-0.98319]}\end{array}$ & $\begin{array}{r}-4.204082 \\
(12.3781) \\
{[-0.33964]}\end{array}$ & $\begin{array}{r}-0.158592 \\
(0.39060) \\
{[-0.40602]}\end{array}$ & $\begin{array}{r}-0.275309 \\
(0.18625) \\
{[-1.47818]}\end{array}$ & $\begin{array}{r}0.102671 \\
(0.07036) \\
{[1.45922]}\end{array}$ & $\begin{array}{r}-0.198472 \\
(0.09037) \\
{[-2.19631]}\end{array}$ \\
\hline DLNM1(-4) & $\begin{array}{c}27.69066 \\
(9.58050) \\
{[2.89032]}\end{array}$ & $\begin{array}{r}17.01857 \\
(12.5469) \\
{[1.35639]}\end{array}$ & $\begin{array}{c}0.295654 \\
(0.39593) \\
{[0.74673]}\end{array}$ & $\begin{array}{r}0.572104 \\
(0.18879) \\
{[3.03039]}\end{array}$ & $\begin{array}{r}-0.057694 \\
(0.07132) \\
{[-0.80895]}\end{array}$ & $\begin{array}{r}0.017875 \\
(0.09160) \\
{[0.19514]}\end{array}$ \\
\hline DLNPDB(-1) & $\begin{array}{r}-29.17912 \\
(21.0289) \\
{[-1.38758]}\end{array}$ & $\begin{array}{r}-26.87659 \\
(27.5401) \\
{[-0.97591]}\end{array}$ & $\begin{array}{r}-1.178285 \\
(0.86905) \\
{[-1.35583]}\end{array}$ & $\begin{array}{r}0.054871 \\
(0.41439) \\
{[0.13242]}\end{array}$ & $\begin{array}{r}-0.149589 \\
(0.15655) \\
{[-0.95556]}\end{array}$ & $\begin{array}{r}-0.428790 \\
(0.20106) \\
{[-2.13270]}\end{array}$ \\
\hline DLNPDB(-2) & $\begin{array}{r}-33.17521 \\
(20.8175) \\
{[-1.59362]}\end{array}$ & $\begin{array}{r}-45.84931 \\
(27.2633) \\
{[-1.68172]}\end{array}$ & $\begin{array}{r}-1.512290 \\
(0.86032) \\
{[-1.75783]}\end{array}$ & $\begin{array}{r}0.228154 \\
(0.41022) \\
{[0.55617]}\end{array}$ & $\begin{array}{r}-0.203252 \\
(0.15497) \\
{[-1.31154]}\end{array}$ & $\begin{array}{r}-0.131487 \\
(0.19903) \\
{[-0.66062]}\end{array}$ \\
\hline $\operatorname{DLNPDB}(-3)$ & $\begin{array}{r}-1.596791 \\
(20.6903) \\
{[-0.07718]}\end{array}$ & $\begin{array}{r}-0.113000 \\
(27.0967) \\
{[-0.00417]}\end{array}$ & $\begin{array}{r}-1.133727 \\
(0.85506) \\
{[-1.32591]}\end{array}$ & $\begin{array}{r}0.049444 \\
(0.40771) \\
{[0.12127]}\end{array}$ & $\begin{array}{r}-0.376660 \\
(0.15402) \\
{[-2.44545]}\end{array}$ & $\begin{array}{r}-0.063850 \\
(0.19782) \\
{[-0.32277]}\end{array}$ \\
\hline DLNPDB(-4) & $\begin{array}{r}20.23994 \\
(19.9195) \\
{[1.01609]}\end{array}$ & $\begin{array}{r}18.34388 \\
(26.0873) \\
{[0.70317]}\end{array}$ & $\begin{array}{r}-1.483279 \\
(0.82320) \\
{[-1.80183]}\end{array}$ & $\begin{array}{r}-0.362621 \\
(0.39253) \\
{[-0.92381]}\end{array}$ & $\begin{array}{c}0.521834 \\
(0.14829) \\
{[3.51908]}\end{array}$ & $\begin{array}{r}-0.221675 \\
(0.19045) \\
{[-1.16396]}\end{array}$ \\
\hline DLNIHK(-1) & $\begin{array}{r}13.82631 \\
(21.1097) \\
{[0.65497]}\end{array}$ & $\begin{array}{r}-26.20371 \\
(27.6460) \\
{[-0.94783]}\end{array}$ & $\begin{array}{r}-1.609337 \\
(0.87239) \\
{[-1.84474]}\end{array}$ & $\begin{array}{r}-0.070567 \\
(0.41598) \\
{[-0.16964]}\end{array}$ & $\begin{array}{r}-0.048634 \\
(0.15715) \\
{[-0.30948]}\end{array}$ & $\begin{array}{r}-0.250250 \\
(0.20183) \\
{[-1.23992]}\end{array}$ \\
\hline DLNIHK(-2) & $\begin{array}{c}4.110925 \\
(19.9055) \\
{[0.20652]}\end{array}$ & $\begin{array}{r}-29.99332 \\
(26.0689) \\
{[-1.15054]}\end{array}$ & $\begin{array}{r}-0.318528 \\
(0.82263) \\
{[-0.38721]}\end{array}$ & $\begin{array}{c}0.279331 \\
(0.39225) \\
{[0.71213]}\end{array}$ & $\begin{array}{c}0.060498 \\
(0.14818) \\
{[0.40827]}\end{array}$ & $\begin{array}{r}-0.267282 \\
(0.19032) \\
{[-1.40442]}\end{array}$ \\
\hline
\end{tabular}




\begin{tabular}{|c|c|c|c|c|c|c|}
\hline \multicolumn{7}{|c|}{$\begin{array}{l}\text { Vector Autoregression Estimates } \\
\text { Sample(adjusted): 1991:2 2007:4 } \\
\text { Included observations: } 67 \text { after adjusting endpoints } \\
\text { Standard errors in ( ) \& t-statistics in [ ] }\end{array}$} \\
\hline & DSBI & DDEP & DLNKURS & DLNM1 & DLNPDB & DLNIHK \\
\hline DLNIHK(-3) & $\begin{array}{r}-46.00114 \\
(20.1325) \\
{[-2.28492]}\end{array}$ & $\begin{array}{r}-43.94383 \\
(26.3663) \\
{[-1.66667]}\end{array}$ & $\begin{array}{r}-1.285632 \\
(0.83201) \\
{[-1.54522]}\end{array}$ & $\begin{array}{r}0.492789 \\
(0.39672) \\
{[1.24215]}\end{array}$ & $\begin{array}{r}-0.153714 \\
(0.14987) \\
{[-1.02563]}\end{array}$ & $\begin{array}{r}0.095369 \\
(0.19249) \\
{[0.49546]}\end{array}$ \\
\hline DLNIHK(-4) & $\begin{array}{r}-43.63190 \\
(18.1705) \\
{[-2.40125]}\end{array}$ & $\begin{array}{r}-32.84421 \\
(23.7967) \\
{[-1.38020]}\end{array}$ & $\begin{array}{r}-0.684239 \\
(0.75092) \\
{[-0.91120]}\end{array}$ & $\begin{array}{r}-0.498432 \\
(0.35806) \\
{[-1.39203]}\end{array}$ & $\begin{array}{r}-0.083814 \\
(0.13527) \\
{[-0.61962]}\end{array}$ & $\begin{array}{r}0.015349 \\
(0.17373) \\
{[0.08835]}\end{array}$ \\
\hline$C$ & $\begin{array}{r}-0.720102 \\
(1.80752) \\
{[-0.39839]}\end{array}$ & $\begin{array}{r}1.429541 \\
(2.36719) \\
{[0.60390]}\end{array}$ & $\begin{array}{r}0.127278 \\
(0.07470) \\
{[1.70388]}\end{array}$ & $\begin{array}{r}0.044881 \\
(0.03562) \\
{[1.26005]}\end{array}$ & $\begin{array}{r}0.025790 \\
(0.01346) \\
{[1.91665]}\end{array}$ & $\begin{array}{r}0.048524 \\
(0.01728) \\
{[2.80784]}\end{array}$ \\
\hline $\begin{array}{l}\text { R-squared } \\
\text { Adj. R-squared } \\
\text { Sum sq. resids } \\
\text { S.E. equation } \\
\text { F-statistic } \\
\text { Log likelihood } \\
\text { Akaike AIC } \\
\text { Schwarz SC } \\
\text { Mean dependent } \\
\text { S.D. dependent }\end{array}$ & $\begin{array}{r}0.935804 \\
0.899120 \\
164.6447 \\
1.979928 \\
25.51017 \\
-125.1886 \\
4.483243 \\
5.305890 \\
-0.232090 \\
6.233719\end{array}$ & $\begin{array}{r}0.828073 \\
0.729829 \\
282.3891 \\
2.592981 \\
8.428743 \\
-143.2618 \\
5.022739 \\
5.845385 \\
-0.283881 \\
4.988616\end{array}$ & $\begin{array}{r}0.787012 \\
0.665305 \\
0.281194 \\
0.081824 \\
6.466427 \\
88.29011 \\
-1.889257 \\
-1.066610 \\
0.023644 \\
0.141434\end{array}$ & $\begin{array}{r}0.700419 \\
0.529230 \\
0.063933 \\
0.039016 \\
4.091494 \\
137.9106 \\
-3.370465 \\
-2.547819 \\
0.044374 \\
0.056864\end{array}$ & $\begin{array}{r}0.879239 \\
0.810232 \\
0.009124 \\
0.014739 \\
12.74138 \\
203.1318 \\
-5.317367 \\
-4.494721 \\
0.010081 \\
0.033835\end{array}$ & $\begin{array}{r}0.853794 \\
0.770247 \\
0.015050 \\
0.018930 \\
10.21938 \\
186.3661 \\
-4.816900 \\
-3.994253 \\
0.027745 \\
0.039493\end{array}$ \\
\hline \multicolumn{2}{|c|}{$\begin{array}{l}\text { Determinant Residual Covariance } \\
\text { Log Likelihood (d.f. adjusted) } \\
\text { Akaike Information Criteria } \\
\text { Schwarz Criteria }\end{array}$} & $\begin{array}{r}2.64 \mathrm{E}-12 \\
322.7308 \\
-5.156142 \\
-0.220263\end{array}$ & & & & \\
\hline
\end{tabular}


halaman ini sengaja dikosongkan 